Research Article

\title{
Evaluation of Carbonation Effects on Cement-Solidified Contaminated Soil Used in Road Subgrade
}

\author{
Yundong Zhou, ${ }^{1,2,3}$ Lingling Pan, ${ }^{4}$ Qiang Tang $\mathbb{D}^{1,2,4}$ Yu Zhang, ${ }^{4}$ Na Yang, ${ }^{4}$ and Cong Lu $^{4}$ \\ ${ }^{1}$ Key Laboratory of Ministry of Education for Geomechanics and Embankment Engineering, Hohai University, \\ Nanjing 210098, China \\ ${ }^{2}$ Geotechnical Research Institute, Hohai University, Nanjing 210098, China \\ ${ }^{3}$ Institute of Geotechnical Engineering, Nanjing University of Technology, Nanjing 210009, China \\ ${ }^{4}$ School of Rail Transportation, Soochow University, Suzhou 215131, China \\ Correspondence should be addressed to Qiang Tang; tangqiang@suda.edu.cn
}

Received 8 October 2017; Accepted 7 December 2017; Published 4 February 2018

Academic Editor: Estokova Adriana

Copyright ( 2018 Yundong Zhou et al. This is an open access article distributed under the Creative Commons Attribution License, which permits unrestricted use, distribution, and reproduction in any medium, provided the original work is properly cited.

Cement solidification/stabilization is widely used towards contaminated soil since it has a low price and significant improvement for the structural capacity of soil. To increase the usage of the solidified matrix, cement-solidified contaminated soil was used as road subgrade material. In this study, carbonation effect that reflected the durability on strength characteristics of cementsolidified contaminated soil and the settlement of pavement were evaluated through experimental and numerical analysis, respectively. According to results, compressive strengths of specimens with $1 \% \mathrm{~Pb}(\mathrm{II})$ under carbonation and standard curing range from $0.44 \mathrm{MPa}$ to $1.17 \mathrm{MPa}$ and $0.14 \mathrm{MPa}$ to $2.67 \mathrm{MPa}$, respectively. The relatively low strengths were attributed to immobilization of heavy metal, which consumed part of $\mathrm{SiO}_{2}, \mathrm{Al}_{2} \mathrm{O}_{3}$, and $\mathrm{CaO}$ components in the cement or kaolin and reduced the hydration and pozzolanic reaction materials. This phenomenon further decreased the strength of solidified soils. The carbonation depth of $1 \% \mathrm{Cu}(\mathrm{II})$ or $\mathrm{Zn}(\mathrm{II})$ contaminated soils was $18 \mathrm{~mm}$, which significantly increased with the increase of curing time and contamination concentration. Furthermore, the finite element calculation results showed that surface settlements decreased with the increase of modulus of subgrade and the distance away from the center. At the center, the pavement settlement was proportional to the level of traffic load.

\section{Introduction}

The development of industry and urbanization was accompanied with soil pollution, which attracts great attention in the recent years [1-4]. Heavy metal pollution in soils in various countries is summarized in Table 1. According to the site-investigation in Southern tailing area, France, the concentration of $\mathrm{Pb}$ (II) contained in soil reached around $9000 \mathrm{mg} / \mathrm{kg}$, which was almost 281 times higher than that of natural soil [5]. Similarly, according to Seleznev and Yarmoshenko and CosKun et al., the soil in Turkey and Russia was also suffered with $\mathrm{Pb}(\mathrm{II})$ contamination [6,7]. Besides, the concentration of $\mathrm{Cu}(\mathrm{II})$ in mining areas in Vietnam were founded as high as $1050 \mathrm{mg} / \mathrm{kg}$ [8]. In China, according to Zhang et al., the concentration of $\mathrm{Cu}(\mathrm{II})$ in Guangdong was founded as high as $4800 \mathrm{mg} / \mathrm{kg}$ [9]. Heavy metals are not only hazardous to the environment and public health but also lead to the degradation of mechanical properties of soils $[10,11]$. Bochenek and Kurdowski found that the effect of solidification/stabilization of the waste is strongly related to the concentration of $\mathrm{Pb}(\mathrm{II})$ and $\mathrm{Zn}(\mathrm{II})$ [12]. The high concentration of heavy metals usually diminishes the solidification/stabilization of the waste.

Solidification/stabilization (S/S) is a commonly used remediation method towards heavy metal-contaminated soils. The S/S process is recognized by the U.S. Environmental Protection Agency (EPA) as the Best Demonstrated Available Technology (BDAT) for the land disposal of most toxic elements [10]. This method not only enhances the strength of soil effectively but also reduces the leaching of 
TABLE 1: Heavy metal pollution of soils in various regions.

\begin{tabular}{|c|c|c|c|c|c|c|c|c|}
\hline \multirow{2}{*}{ Country } & \multirow{2}{*}{ Location } & \multicolumn{6}{|c|}{ Metal content $(\mathrm{mg} / \mathrm{kg})$} & \multirow{2}{*}{ References } \\
\hline & & $\mathrm{Cr}$ & $\mathrm{Pb}$ & $\mathrm{Cu}$ & $\mathrm{Zn}$ & $\mathrm{Cd}$ & $\mathrm{Ni}$ & \\
\hline China & Guangdong & 2600 & 150 & 4800 & 330 & 1.21 & 480 & [9] \\
\hline China & A rural area, Jianghan plain & 253.8 & 4.88 & 64.6 & - & 20.3 & 589.5 & {$[13]$} \\
\hline Russia & Ekaterinburg & - & 1027 & 370 & - & - & 663 & {$[6]$} \\
\hline France & Southern tailing area & - & 9000 & - & 16,000 & - & - & {$[5]$} \\
\hline Turkey & 73 places & 830 & 968 & 167 & 165 & 1.7 & 249 & {$[7]$} \\
\hline Greece & Landfill site & 172 & 93 & 356 & 344 & 18.8 & 66 & {$[14]$} \\
\hline Vietnam & Mining areas & 135 & - & 1050 & - & 284 & 76.9 & [8] \\
\hline India & Nuggihalli, Karnataka & 4863 & 84.1 & 153.6 & - & - & 1398 & [15] \\
\hline \multicolumn{2}{|c|}{ Background value in soil } & 133 & 31.8 & 41 & 114 & 0.314 & 58 & {$[16]$} \\
\hline
\end{tabular}

heavy metals [11]. Numerous researchers have studied S/S process to immobilize heavy metal by means of various $S / S$ agents such as cement, quicklime, hydrated lime, fly ash, and cement kiln dust $[17,18]$. Cement is widely used in $S / S$ due to its relative low price and significant improvement for the structural capacity of soil [19].

Conventionally, carbonation reaction of concrete is considered unfavorable, as it diminishes the durability of such materials, but for S/S system, this is different [20]. Exposure of S/S-treated waste to carbon dioxide resulted in physical and chemical transformations, which affected the long-term effectiveness of the S/S process. The microcracks were generated in the carbonated areas, which decreased the strength of concrete [21]. Gunning et al. demonstrated that accelerated carbonation could enhance the curing property of cement solidification and reduce the cost of disposal processes [22]. Although many studies investigated the carbonation reaction, its effects on the strength of contaminated soil that is solidified by cement still have not been systematically studied.

Road is the main transport infrastructure and an important stimulator to the economy. In order to meet the increasing demands in terms of axle loads and frequency of traffic, the entire road network demands a substantial amount of aggregates, bituminous, and cementitious binders [23]. Recently, with the increase of scarcity of raw materials, the road pavement industry is facing new challenges in terms of resources. Numerous laboratory studies and field trials have shown that recycled materials can totally or partially replace natural materials in road construction [24]. Brooks and Cetin confirmed that using 30\% recycled demolition waste and cement kiln dust to strengthen the subgrade and to prepare the subbase helps reducing the overall thickness of the pavement [25]. Bennert et al. studied the performance of recycled concrete aggregate in base and subbase courses and concluded that a mixture of $25 \%$ of recycled concrete aggregates with $75 \%$ of natural aggregate has the same resilient response [26]. In China, contaminated soils in industrial sites including power plants and boiler plants which stabilized by cement were used as road materials for Shanghai, World Expo. Potential saving in raw materials and storage space made the use of solidified soil, an attractive alternative to highway engineers.
The solidified contaminated soil instead of raw material is used as subgrade material. In the field of practical engineering, due to the limitations of the construction environment, the contaminated soil is inevitably exposed to atmospheric carbon dioxide before strength formation. Carbon dioxide in the disposal environment enters into the pores of the contaminated soils during the curing period. Previous studies show that carbonation of S/S-treated material brings about physical and chemical transformations that can affect the long-term effectiveness of the S/S process [27]. Therefore, the simulation of the solidified contaminated soil after carbonation and the evaluation of its durability deserve to be studied.

In this paper, soils spiked with high levels of $\mathrm{Pb}(\mathrm{II})$, $\mathrm{Zn}$ (II), and $\mathrm{Cu}$ (II) contaminants were treated by cement as subgrade material. The objectives of this study are to systematically investigate the effects of carbonation on the strength of the cement-stabilized soils through the laboratory tests. The influence factors included the type and content of heavy metals, cement content, moisture content, and curing time. The mechanisms of $\mathrm{Zn}$ (II), $\mathrm{Pb}$ (II), and $\mathrm{Cu}$ (II) immobilization with cement are interpreted based on the results of X-ray diffraction (XRD), Inductive Coupled Plasma Emission Spectrometer (ICP), nitrogen adsorption measurement $\left(\mathrm{N}_{2}\right.$-BET), and scanning electron microscope (SEM) analysis. Subsequently, MIDAS/GTS finite element program is used to investigate the pavement settlements of application of solidified contaminated soil in subgrade. The final section summarizes the major findings of this study.

\section{Materials and Methods}

2.1. Raw Materials. The soils used in this study included one type of clay and one type of fine sand. The clay was commercial kaolin, obtained from Suzhou kaolin Co. Ltd., China. Commercial sand with diameters of approximately $1.0 \mathrm{~mm}$ was obtained from ShengFa Building Materials Co. Ltd., China. As the binder material, the commercially available OPC P.O42.5 was prepared, which consisted of $6 \%-15 \%$ active additive and $85 \%-94 \%$ cement. The natural moisture content of kaolin and sand was measured according to JIS A 1203. Grain size distribution of kaolin and sand was tested according to GB/T 50123-1999. Electrical 
TABLE 2: Mixture composition of specimens.

\begin{tabular}{lcccc}
\hline No. & Heavy metal & Metal content (\%) & Cement content (\%) & Moisture content (\%) \\
\hline 1 & 0 & 0 & 5 & 17 \\
2 & 0 & 0 & 5 & 17 \\
3 & 0 & 0 & 10 & 23 \\
4 & 0 & 0 & 10 & 17 \\
5 & $\mathrm{~Pb}$ & 0.1 & 5 & 23 \\
6 & $\mathrm{~Pb}$ & 0.1 & 5 & 17 \\
7 & $\mathrm{~Pb}$ & 1 & 5 & 23 \\
8 & $\mathrm{~Pb}$ & 1 & 5 & 17 \\
9 & $\mathrm{~Pb}$ & 1 & 10 & 23 \\
10 & $\mathrm{~Pb}$ & 1 & 10 & 23 \\
11 & $\mathrm{Zn}$ & 1 & 10 & 23 \\
12 & $\mathrm{Cu}$ & 1 & 10 & 23 \\
\hline
\end{tabular}

conductivity (EC) and $\mathrm{pH}$ of the kaolin and sand was measured by $\mathrm{pH} / \mathrm{EC}$ meter (PH-2603, Lohand, China) following JGS 0212 and JGS 0211, respectively. The $\mathrm{N}_{2}$-BET adsorption test was conducted to analyze specific surface area and average pore diameter of soil (NOVA2000e, Quantachrome, U.S.). The elemental and mineral composition of kaolin was analyzed by ICP-OES (Varian 720) and XRD (RAD-2B, Rigaku Corporation, Japan) correspondingly.

Firstly, soils and $\mathrm{H}_{2} \mathrm{O}_{2}$ were directly weighed inside the quartz vessels. The rotor was positioned inside the SRC system, which was previously filled with $120 \mathrm{~mL}$ of water and $5 \mathrm{~mL}$ of $\mathrm{H}_{2} \mathrm{SO}_{4}$. Secondly, the microwave heating procedure was operated as follows: $10 \mathrm{~min}$ of ramp and hold for $20 \mathrm{~min}$ at $250^{\circ} \mathrm{C}$. After cooling down $\left(65^{\circ} \mathrm{C}\right)$, the chamber was depressurized, and the resultant solution was diluted in volumetric flasks up to $25 \mathrm{~mL}$. After that, the residue was carefully transferred into microwave digestion system to which $8 \mathrm{~mL}$ of a mixture of $20 \% \mathrm{HNO}_{3}+5 \% \mathrm{HF}+5 \% \mathrm{H}_{2} \mathrm{O}_{2}$ or $20 \% \mathrm{HNO}_{3}+0.4 \% \mathrm{NH}_{4} \mathrm{HF}_{2}+5 \% \mathrm{H}_{2} \mathrm{O}_{2}$ was added [28]. Finally, the vessel was closed and clamped within a support module and placed inside the microwave digestion system.

The heavy metal-contaminated soils were prepared artificially by adding $\mathrm{Pb}\left(\mathrm{NO}_{3}\right)_{2}, \mathrm{Zn}\left(\mathrm{NO}_{3}\right)_{2} \cdot 6 \mathrm{H}_{2} \mathrm{O}$, and $\mathrm{Cu}\left(\mathrm{NO}_{3}\right)_{2}$ (Analytical reagent, Sinopharm, China) as a source of pollutant. $\mathrm{Zn}$ (II) and $\mathrm{Pb}$ (II) were selected as the target heavy metals because they are commonly encountered in the contaminated sites worldwide, especially in China $[29,30]$. The reason for choosing the source chemical in nitrate form was that the main chemical compositions of cement including $\mathrm{Ca}(\mathrm{II})$ and $\mathrm{K}(\mathrm{I})$ are very inert to react with nitrate anions. Besides, when compared to phosphate anions, nitrate anions have low sensitivity to the engineering characteristics of clay.

2.2. Specimen Preparation. Before the experiment, kaolin, cement, and sand samples were oven dried at $105^{\circ} \mathrm{C}$ for 24 hours (h) (101-A, Leao, China) and then cooled to room temperature in a desiccator $[31,32]$. First of all, according to the ratio of sand/kaolin ( $7: 3$ by dry mass), samples were carried out and mixed manually for 4-5 minutes ( $\mathrm{min}$ ) in the vessel to achieve homogeneity. Second, cement was then added according to the ratios of cement/soils (5\%/10\%, on dry weight of soil basis), recorded as C5/C10. Third, based on the mixture proportion shown in Table 2, the heavy metal solutions were prepared artificially by adding $\mathrm{Pb}\left(\mathrm{NO}_{3}\right)_{2}$, $\mathrm{Zn}\left(\mathrm{NO}_{3}\right)_{2} \cdot 6 \mathrm{H}_{2} \mathrm{O}$, and $\mathrm{Cu}\left(\mathrm{NO}_{3}\right)_{2}$ (Analytical reagent, Sinopharm, China). After the mixing procedure, the mixture was transferred into a mold, which is $5 \mathrm{~cm}$ in diameter and $10 \mathrm{~cm}$ in height. At last, the specimens were extruded from the molds carefully with a hydraulic jack and were sealed with a polyethylene membrane to avoid severe dehydration.

After molding, partial samples were cured ( $\geq 95 \%$ humidity, $20 \pm 2^{\circ} \mathrm{C}$ ) for $1,7,14$, and 28 days in a curing box (HBY-15B, Donghua, China). In addition, the rest of samples were placed in a carbonation testing apparatus $(75 \pm 5 \%$ humidity, $20 \pm 2^{\circ} \mathrm{C}$ ) containing $\mathrm{CO}_{2}$ gas at the concentration of $20 \pm 2 \%$ for $1,7,14$, and 28 days. According to $\mathrm{Pu}$ and Unluer, the demolded samples were subjected to accelerated carbonation at $30 \pm 2{ }^{\circ} \mathrm{C}$ and $80 \pm 5 \% \mathrm{RH}$ under a $\mathrm{CO}_{2}$ concentration of $10 \%$ for up to 28 days [33]. On the basis of Tang et al. (2017)'s research, the cement-fly ash mixtures were demoulded and placed in a carbonation testing apparatus containing $\mathrm{CO}_{2}$ gas concentration of $20 \pm 3 \%$, relative humidity of $70 \pm 2 \%$, and temperature of $20 \pm 2{ }^{\circ} \mathrm{C}$ for 7 , 14 , and 28 days, which in accordance with the experimental scheme in this study [34]. In this study, the accelerated carbonation $\left(\mathrm{CO}_{2}\right.$ concentration of $\left.20 \pm 2 \%\right)$ was used to simulate the long-term effects of carbonation on the strength and leaching characteristics of cement-stabilized contaminated soils.

2.3. Compressive Strength Test. After curing, the unconfined compression tests were conducted as per ASTM D 2166-91 using a microcomputer-controlled electronic testing machine (LDS-50, Chenda, China), with a vertical displacement rate of $1 \mathrm{~mm} / \mathrm{min}$. The shape factor (height-to-diameter ratio) of the $\mathrm{CPB}$ specimens was 2.0. Total maximum loads were recorded, and the compressive strength was determined using the formula $q_{u}=\mathrm{F} / \mathrm{A}$, where $q_{u}$ is the 
compressive strength (MPa), $\mathrm{F}$ is the total maximum load $(\mathrm{N})$, and A is the area of loaded surface $\left(\mathrm{mm}^{2}\right)$. Based on the accuracy of the experiment, all of these tests were conducted in replicate, and the average values were reported.

2.4. Carbonation Depth Test. The carbonated specimens were cut in half on the basis of splitting method, which were followed by removing residual powder. The freshly cut surfaces were sprayed with phenolphthalein, which turned pink where the pore solution exceeded $\mathrm{pH}$ 9, that is, where the matrix had not yet become carbonated [35]. As shown in Figure 1, the depth of carbonation $L$ was measured at four different locations along four edges, and the average value was used to determine the extent of carbonation according to GB/T 50082-2009 [36]:

$$
L=\frac{\left(L_{1}+L_{2}+L_{3}+L_{4}\right)}{4} .
$$

2.5. Numerical Simulation Model. Pavement is a multilayered structure composed of a concrete slab or an asphalt layer laid on a foundation system comprising various layers such as base and subgrade [37-43].

MIDAS/GTS finite element software was adopted to assess the structural capacity of pavement with the use of cement-solidified contaminated soil used in subgrade. The influences of subgrade modulus and vehicle load on the structural surface deflection were analyzed. In this paper, schematic plot of road structure is shown in Figure 2. The pavement structure is simplified as a two-dimensional (2D) axisymmetric plane strain case $[44,45]$.

In this model, the pavement length along the traffic direction was assumed infinite. The width of the subgrade was defined as 40 meters, while the road width was onefourth of the subgrade. This setting was to eliminate the interference of boundary condition on the results. Besides, the depth of the model was 3 meters. The pavement structure comprised various layers including $18 \mathrm{~cm}$ asphalt layer, $40 \mathrm{~cm}$ cement treated base layer, and $242 \mathrm{~cm}$ cementsolidified contaminated soil layer. The details of the model (constitutive model, thickness, and basic properties of each layer) are shown in Table 3.

In pavement structure design, the axial load is usually assumed to be uniformly distributed on the contact area [46]. According to BZZ-100 standard axle load, axle load was $100 \mathrm{kN}$ and contact pressure was $0.7 \mathrm{MPa}$. The contact area between tire and road surface was $0.134 \mathrm{~m}^{2}$ in accordance with JTG D50-2006. The loading area was located at the center of the pavement illustrated in Figure 2, and the radius $r_{0}$ was $0.152 \mathrm{~m}$. In order to eliminate the boundary effect, the bottom boundary was set to be completely fixed, and the side boundary was fixed in the lateral direction.

It is known that there is a correlation between modulus of cement-treated material and the strength of aggregate used [37]. Terashi et al. indicated that secant modulus (E50) had a linear correlation with $q_{u}$ expressed by (2) [47]. Experimental findings according to $\mathrm{Du}$ et al. were that the dimensionless fitting parameter $\eta$ varies in the range of

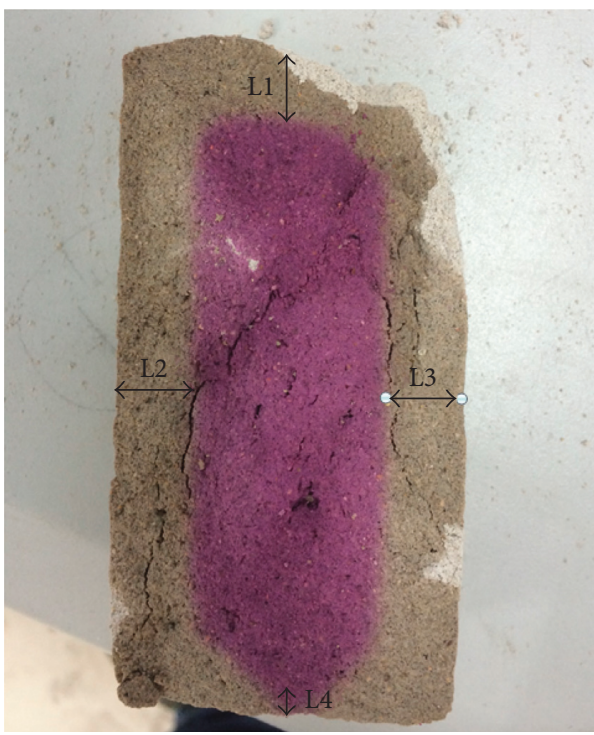

Figure 1: Carbonation depth of specimen.

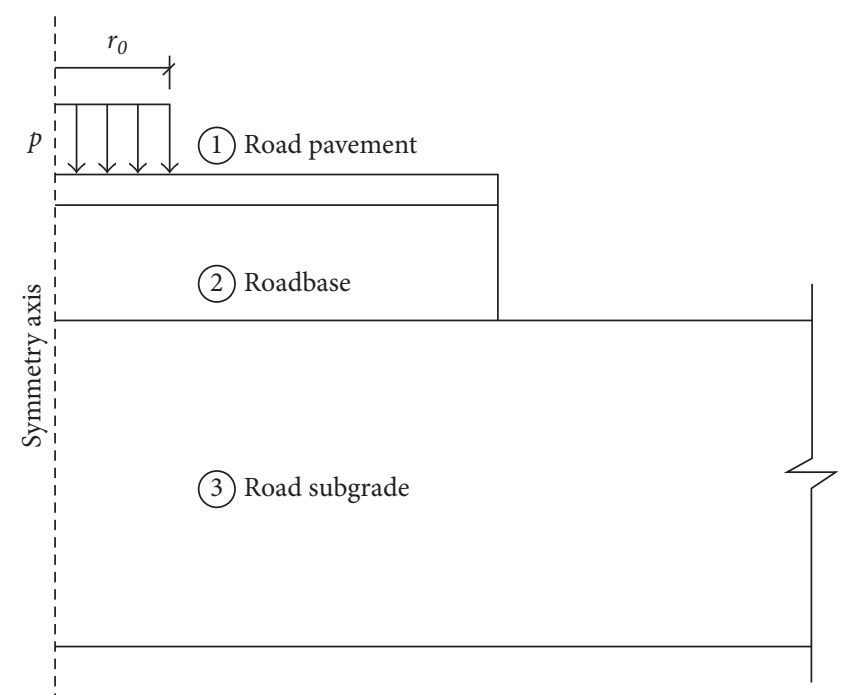

Figure 2: Schematic plot of road structure.

18 to 53 , depending on heavy metal concentration and cement content [48]. Yang and Zhao investigated the relationship between deformation modulus $\left(E_{S}\right)$ and modulus of elasticity (E), as shown in (3) and (4) [49]. Consequently, the elastic modulus of solidified contaminated soil was calculated based on (5).

$$
\begin{aligned}
E_{50} & =\eta * q_{u}, \\
E_{0} & =\frac{(1+\mu)(1-2 \mu)}{(1-\mu)} E_{S}, \\
E & =(2.5 \sim 3.5) E_{S}, \\
E & =(2.5 \sim 3.5) \frac{(1-\mu)}{(1+\mu)(1-2 \mu)} E_{0},
\end{aligned}
$$


TABLE 3: Input parameters of finite element model.

\begin{tabular}{|c|c|c|c|}
\hline Material & Asphalt mixture & $\begin{array}{c}2 \\
\text { Cement-steadied grit }\end{array}$ & Solidified contaminated soil \\
\hline Constitutive model & Elasticity & Elasticity & Mohr-Coulomb \\
\hline Thickness (m) & 0.18 & 0.40 & 2.42 \\
\hline Bulk density $\left(\mathrm{kN} / \mathrm{m}^{3}\right)$ & 19.6 & 23.5 & 17.4 \\
\hline Elasticity modulus (MPa) & 1400 & 500 & 30 \\
\hline Cohesive force $(\mathrm{kPa})$ & l & l & 24 \\
\hline Internal friction angle $\left({ }^{\circ}\right)$ & / & l & 30 \\
\hline Poisson's ration & 0.35 & 0.25 & 0.45 \\
\hline
\end{tabular}

TABLe 4: Physical and mechanical properties of kaolin and sand.

\begin{tabular}{|c|c|c|c|c|}
\hline Properties & Standard & Unit & Kaolin & Sand \\
\hline Natural water content & JIS A 1203 & $\%$ & 2.90 & 0.39 \\
\hline $\mathrm{pH}$ & JGS 0211 & - & 4.70 & 7.50 \\
\hline $\mathrm{EC}$ & JGS 0212 & $\mathrm{mS} / \mathrm{cm}$ & 0.42 & 0.06 \\
\hline Grain size distribution & GB/T50123-1999 & - & - & - \\
\hline Clay fraction $(\leq 0.005 \mathrm{~mm})$ & - & $\%$ & 56.40 & 0.10 \\
\hline Silt fraction $(0.075-0.005 \mathrm{~mm})$ & - & $\%$ & 18.80 & 2.98 \\
\hline Sand fraction $(2-0.075 \mathrm{~mm})$ & - & $\%$ & 24.80 & 96.92 \\
\hline Correlation coefficient $(R)$ & - & - & 0.99 & - \\
\hline Specific surface area & - & $\mathrm{m}^{2} / \mathrm{g}$ & 29.41 & - \\
\hline Average pore size & - & $\mathrm{nm}$ & 29.97 & - \\
\hline Total pore volume & - & $\mathrm{cm}^{3} / \mathrm{g}$ & 0.22 & - \\
\hline
\end{tabular}

TABle 5: Soil compounds identified by ICP.

\begin{tabular}{lccccc}
\hline Element & Unit & Concentration & Element & Unit & Concentration \\
\hline $\mathrm{Al}$ & $\mathrm{mg} / \mathrm{kg}$ & $11,900.1$ & $\mathrm{Na}$ & $\mathrm{mg} / \mathrm{kg}$ & 3167.3 \\
$\mathrm{Ca}$ & $\mathrm{mg} / \mathrm{kg}$ & 3024.41 & $\mathrm{Si}$ & $\mathrm{mg} / \mathrm{kg}$ & $50,266.8$ \\
$\mathrm{~K}$ & $\mathrm{mg} / \mathrm{kg}$ & 2303.5 & $\mathrm{Ti}$ & $\mathrm{mg} / \mathrm{kg}$ & 3492.9 \\
$\mathrm{Fe}$ & $\mathrm{mg} / \mathrm{kg}$ & 5520.2 & $\mathrm{Zn}$ & $\mathrm{mg} / \mathrm{kg}$ & 344.76 \\
$\mathrm{Mg}$ & $\mathrm{mg} / \mathrm{kg}$ & 171.02 & $\mathrm{~Pb}$ & $\mathrm{mg} / \mathrm{kg}$ & 116.99 \\
\hline
\end{tabular}

where $E_{50}$ is secant modulus $(\mathrm{MPa}) ; \eta$ is a dimensionless fitting parameter; according to Du et al. [48], values of $\eta$ of uncontaminated soil, $\mathrm{Pb} 0.1$, and $\mathrm{Pb} 1$ are determined as 40 , 28 , and 18 , respectively; $E_{0}$ is deformation modulus ( $\left.\mathrm{MPa}\right)$, according to Gong (2008), the deformation modulus was replaced by $E_{50}$ [50]; $\mu$ is Poisson ratio; $E_{S}$ is modulus of compressibility ( $\mathrm{MPa})$; and $E$ is elastic modulus (MPa). The elastic modulus was applied to the numerical simulation in this paper.

\section{Experimental Results and Discussion}

3.1. Characterization of the Materials. The physical and chemical characteristics of soils are summarized in Table 4. As shown in Table 4, the moisture content of kaolin and sand are $2.90 \%$ and $0.39 \%$, respectively. The $\mathrm{pH}$ value of kaolin is 4.70 , which indicates its acid nature. The $\mathrm{pH}$ value of sand is
7.50, which is similar to the soil used in Du et al. [51]. EC values of kaolin and sand are $0.42 \mathrm{mS} / \mathrm{cm}$ and $0.06 \mathrm{mS} / \mathrm{cm}$, respectively.

Concerning the $\mathrm{N}_{2}$-BET adsorption tests, the correlation coefficient is 0.99 , indicating that the obtained results are reliable. The specific surface area of kaolin used in this experiment is $29.41 \mathrm{~m}^{2} / \mathrm{g}$. In addition, the total pore volume and micropore aperture of kaolin are $0.22 \mathrm{~cm}^{3} / \mathrm{g}$ and $29.97 \mathrm{~nm}$, respectively. ICP results of kaolin and sand are presented in Table 5. Based on the XRD spectra shown in Figure 3, kaolin is mainly composed of kaolinite $\left(\mathrm{Al}_{2} \mathrm{Si}_{2} \mathrm{O}_{5}(\mathrm{OH})_{4}\right)$ and lizardite $\left(\mathrm{Mg}_{3} \mathrm{Si}_{2} \mathrm{O}_{5}(\mathrm{OH})_{4}\right)$, which are observed at $2 \theta=12.46^{\circ}, 36.01^{\circ}$, and $24.97^{\circ}$. Considering the existence of $\mathrm{Na}(\mathrm{I})$ and $\mathrm{Fe}$ shown by ICP results, the characteristic peaks at $2 \theta=26.73$ and $20.43^{\circ}$ indicate the presence of sodium phosphate hydrate $\left(\mathrm{Na}_{6} \mathrm{P}_{6} \mathrm{O}_{18} \cdot 6 \mathrm{H}_{2} \mathrm{O}\right)$ and iron silicon carbide (Fe-Si-C). 


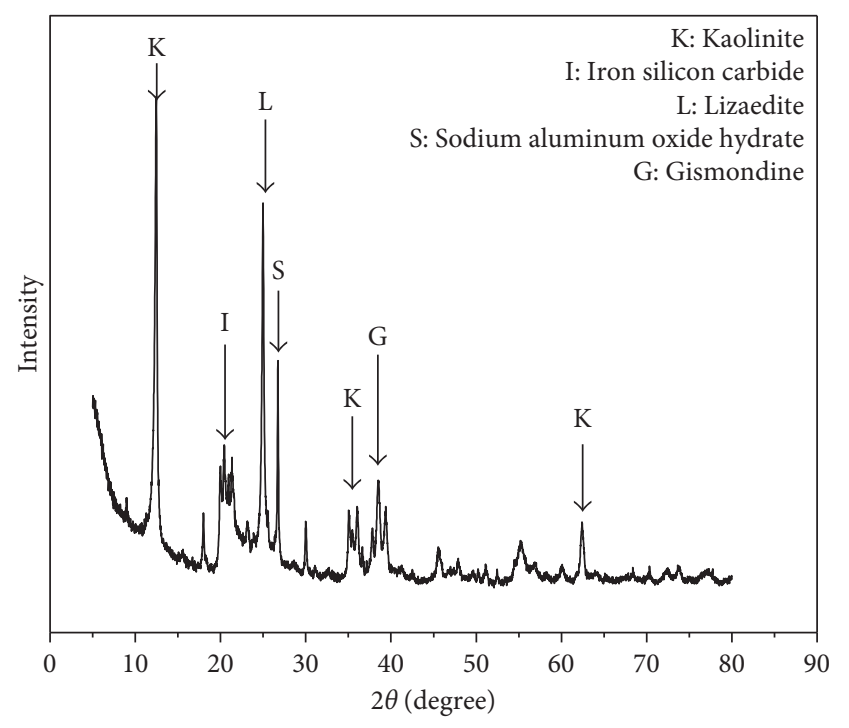

FIGURE 3: XRD analysis of kaolin.

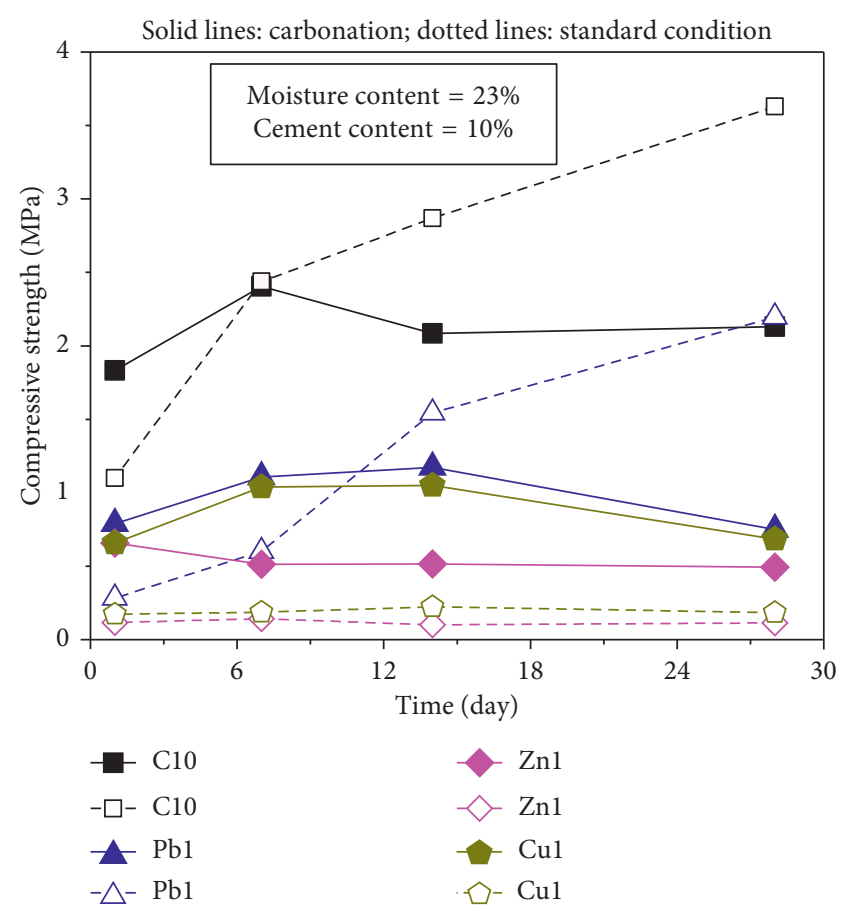

FIGURE 4: The unconfined compressive strength of solidified soil with different contaminations.

3.2. Compressive Strength Analysis. Figure 4 shows the variation in compressive strength values of the stabilized soils with different initial contamination species in which "C10" represent the uncontaminated soil with $10 \%$ cement content. The solid lines represent the carbonated specimens, while the dotted lines represent samples cured under standard conditions. As presented, initial contamination species have different effects on the compressive strength of stabilized soils. Under the standard curing condition, the uncontaminated soil after 1 day (d) of curing exhibits the highest compressive strength, which is $1.1 \mathrm{MPa}$. The strength of uncontaminated soil increases with curing time. As far as $\mathrm{Pb}$ (II) contaminated soil ( $\mathrm{Pb} \mathrm{1)}$, the compressive strength is lower than that of clean soil during 28 days (d) curing periods. The compressive strength of $\mathrm{Cu}$ (II) or $\mathrm{Zn}$ (II) contaminated soil (Cu1/Zn1) shows no significant growth trend, which is only 5 percent of that of clean soil after 28 days (d) of curing. This is because the presence of $\mathrm{Cu}$ (II) or $\mathrm{Zn}$ (II) has a negative impact on the hydration reaction, which hinders the reactions of soils, cement, and contamination. $\mathrm{Pb}(\mathrm{II})$ exists mainly as $\mathrm{Pb}$ hydrate phases and $\mathrm{Pb}$ hydroxide $\left(\mathrm{Pb}(\mathrm{OH})_{2}\right)$ precipitated on the surface of calcium hydroxide $\left(\mathrm{Ca}(\mathrm{OH})_{2}\right)$ or calcium silicate hydrate (CSH). Compared to $\mathrm{Pb}(\mathrm{OH})_{2}$, pyromorphite has a much lower solubility and a greater capacity to resist acid or alkaline attack $[52,53]$. In addition, the solubility of $\mathrm{Zn}_{3}\left(\mathrm{PO}_{4}\right)_{2} \cdot 4 \mathrm{H}_{2} \mathrm{O}$ or $\mathrm{CaZn}_{2}\left(\mathrm{PO}_{4}\right)_{2} \cdot 2 \mathrm{H}_{2} \mathrm{O}$ is much lower than zinc hydroxide $\left(\mathrm{Zn}(\mathrm{OH})_{2}\right)$, which is the main product involved in the immobilization of $\mathrm{Zn}(\mathrm{II})$ with Portland cement [54].

Under carbonation condition, the compressive strength of soils with $1 \% \mathrm{~Pb}$ (II) or $\mathrm{Cu}$ (II) contamination increases slightly during the early stage (1-14 days), while decreases at the late stage (14-28 days). The typical SEM images for kaolin are shown in Figure 5. It is obvious that the microstructure of kaolin is sheet-shaped, whose specific surface area is $29.41 \mathrm{~m}^{2} / \mathrm{g}$. Therefore, $\mathrm{CO}_{2}$ trends to enter the stabilized soil at the early stage due to the large pore size and total pore volume of kaolin. As a result, calcium carbonate hydrate promoted by $\mathrm{CO}_{2}$ with heavy metal possesses high cementitious bonding strength and effectively fills soil macropores [55]. Carbonation mainly involves the primary hydration products: calcium silicate hydrate (CSH) and calcium hydroxide $\left(\mathrm{Ca}(\mathrm{OH})_{2}\right)$, which are converted to calcium carbonate $\left(\mathrm{CaCO}_{3}\right)$, according to the following stoichiometry [56]:

$$
\mathrm{Ca}^{2+}+2(\mathrm{OH})^{-}+\mathrm{CO}_{2}(\mathrm{aq}) \rightarrow \mathrm{CaCO}_{3}(\mathrm{~s})+\mathrm{H}_{2} \mathrm{O}
$$

This assumption is based on the abundance of calcium ions in the pore water due to the dissolution of portlandite. The carbonation reaction is supported by calcium hydroxide that is generated by the decalcification of CSH gel after the original level of portlandite formed during depletion of ordinary Portland cement (OPC) hydration [57]:

$$
\begin{aligned}
x \mathrm{CaO} \cdot \mathrm{SiO}_{2} \cdot n \mathrm{H}_{2} \mathrm{O}+y \mathrm{H}_{2} \mathrm{O} \rightarrow & (x-y) \mathrm{CaO} \cdot \mathrm{SiO}_{2} \cdot n \mathrm{H}_{2} \mathrm{O} \\
& +y \mathrm{Ca}(\mathrm{OH})_{2}
\end{aligned}
$$

$$
\mathrm{CSH}+\mathrm{HCO}_{3}^{-} \rightarrow \mathrm{CaCO}_{3}+\mathrm{SiO}_{2}(\text { gel })+\mathrm{H}_{2} \mathrm{O}
$$

Long-term attack by carbonic acid decomposes the CSH gel into calcium carbonate, acid-insoluble silica gel, and water. However, soil environment changes along with time, resulting in the decrease of compressive strength of stabilized soil.

Compared with carbonated specimens, the soil with $1 \%$ $\mathrm{Pb}$ (II) contamination cured under standard condition shows a higher compressive strength after 14 days of curing. This is 


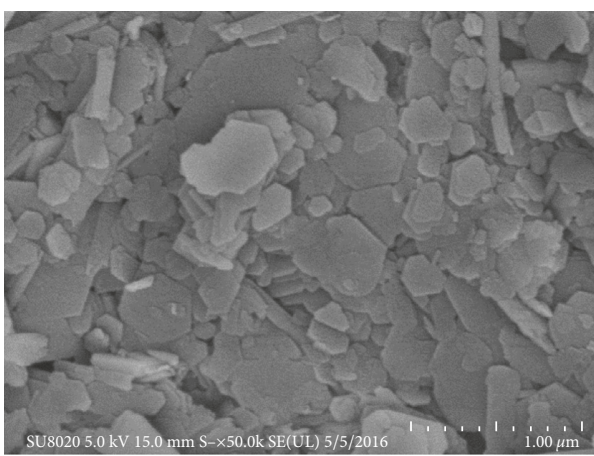

(a)

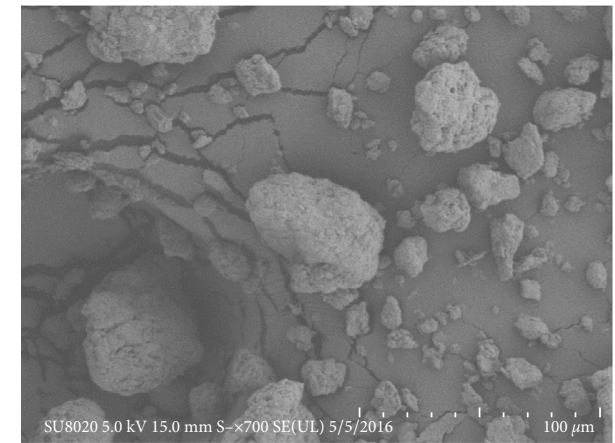

(b)

FIgURE 5: SEM images of kaolin. (a) $1 \mu \mathrm{m}$. (b) $100 \mu \mathrm{m}$.

attributed to its constant hydration reaction. Other researchers have reported similar strength gains caused by carbonation during curing. They attributed this increase to the transformation of calcium hydroxide (the most abundant cement hydration product after $\mathrm{CSH}$ ) to calcium carbonate with lower density, which grows into and fills the cement matrix pores [58]. Meanwhile, the hydration reactions of $\mathrm{Cu}(\mathrm{II})$ or $\mathrm{Zn}$ (II) contaminated soils are delayed, so that the $\mathrm{Cu}(\mathrm{II})$ or $\mathrm{Zn}(\mathrm{II})$ contaminated soils (Cul or Pbl) during 28 days (d) curing periods show lower compressive strengths than those of carbonated specimens.

The relationship between the compressive strength of stabilized soil and the concentration of heavy metal is presented in Figure 6. The notion, "C5," shown in Figure 6 represents the uncontaminated soil with $5 \%$ cement content. It is observed that the concentration of heavy metal has a remarkable effect on soil strength in both conditions. Under the standard curing condition, the compressive strengths of stabilized soils during 7-28 days (d) curing periods decline sharply when the concentration of $\mathrm{Pb}(\mathrm{II})$ increases from $0.1 \%$ to $1 \%$. The strength of $0.1 \% \mathrm{~Pb}(\mathrm{II})$ contaminated soil is slightly lower than that of clean soil at the medium stage (7-14 days). At the same time, the soil with the concentration of $1 \% \mathrm{~Pb}(\mathrm{II})$ after 1 day (d) of curing exhibits the lowest strength, which is only $0.18 \mathrm{MPa}$. After carbonation, the specimens with $1 \% \mathrm{~Pb}(\mathrm{II})$ contamination declines from 0.97 MPa to 0.44 MPa at the late stage (14-28 days), which is more than twice of that uncontaminated soil. When the $\mathrm{Pb}$ (II) ions/soils ratio is small, the formation of lead oxide hydrate $\left(\mathrm{xPbO} \mathrm{yH} \mathrm{H}_{2} \mathrm{O}\right)$ will take place, which possess high cementitious bonding strength. As the $\mathrm{Pb}(\mathrm{II})$ concentration in soil increases, $\mathrm{Pb}(\mathrm{II})$ is bonded by $\mathrm{OH}^{-}$in pore water, and the hydration reaction is incomplete [59]. This leads to the decrease in compressive strength associated with high heavy metal concentration.

The compressive strength values of the solidified soil with different cement contents are presented in Figure 7, in which "Pb1 C5" or "Pb1 C10" represent the $1 \% \mathrm{~Pb}(\mathrm{II})$ contaminated soil with $5 \%$ or $10 \%$ cement content. Under the standard curing condition, the specimens with $10 \%$ cement content show significantly higher strengths than those with lower cement content. As far as carbonated specimens, the soils exhibit higher compressive strengths

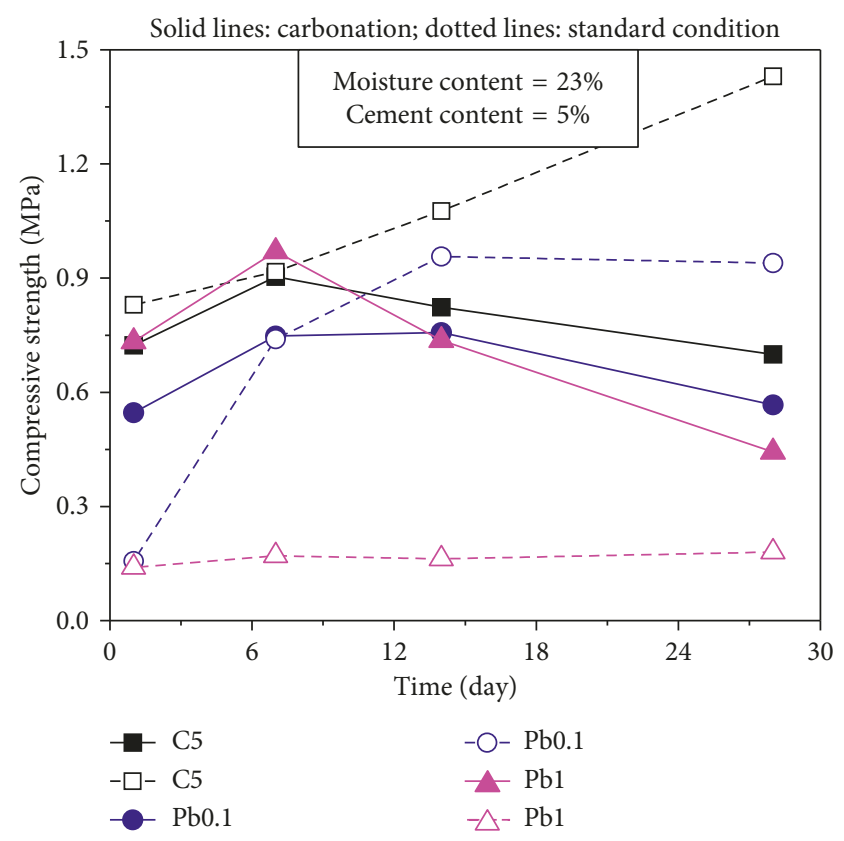

FIgURE 6: The unconfined compressive strength of solidified soil with different heavy metal contents.

during the early stage (1-14 days), while show lower strengths at the late stage (14-28 days). This phenomenon is due to the components of kaolin and cement. As shown in Table 5, the concentration of Si(II) element is measured as high as $50,266.8 \mathrm{mg} / \mathrm{kg}$. The XRD analysis demonstrates that the concentrations of $\mathrm{Al}(\mathrm{III})$ and $\mathrm{Ca}(\mathrm{II})$ in kaolin are $11,900.1 \mathrm{mg} / \mathrm{kg}$ and $3024.4 \mathrm{mg} / \mathrm{kg}$, respectively. Note that $\mathrm{PbO}$ is capable of reacting with both acid and base. As a result, the formation of silicate, aluminate, and plumbite will occur through the reaction of $\mathrm{PbO}$ with $\mathrm{SiO}_{2}, \mathrm{CaO}$, and $\mathrm{Al}_{2} \mathrm{O}_{3}$, respectively. When the cement/soils ratio is small, the immobilization of lead consumed large amounts of $\mathrm{SiO}_{2}$, $\mathrm{CaO}$, and $\mathrm{Al}_{2} \mathrm{O}_{3}$, which results in the decrease of the occurrence of hydration reaction and pozzolanic reaction $[60,61]$.

Figure 8 draws the relationship between strengths and the moisture contents. The notions, "17\% or $23 \%$," represent 


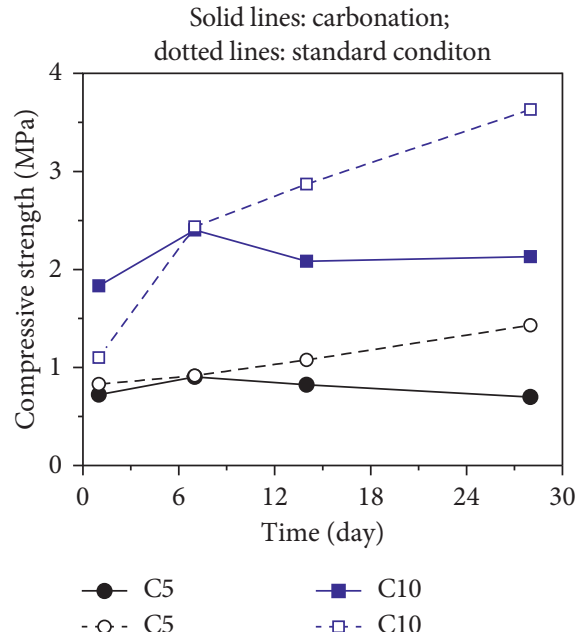

(a)

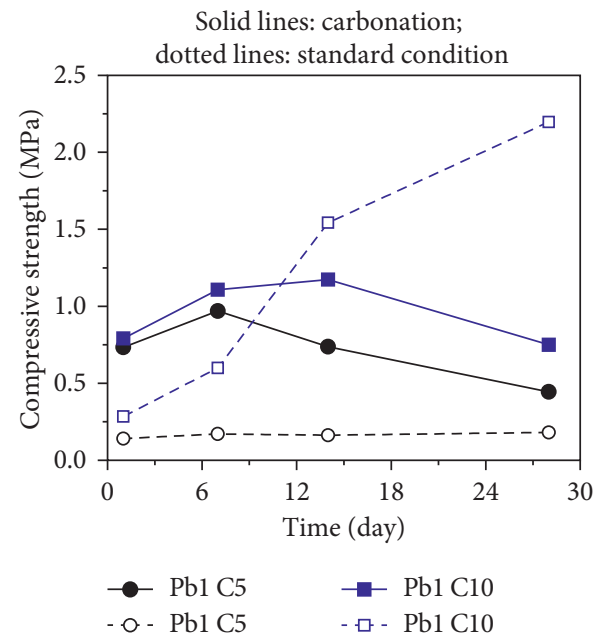

(c)

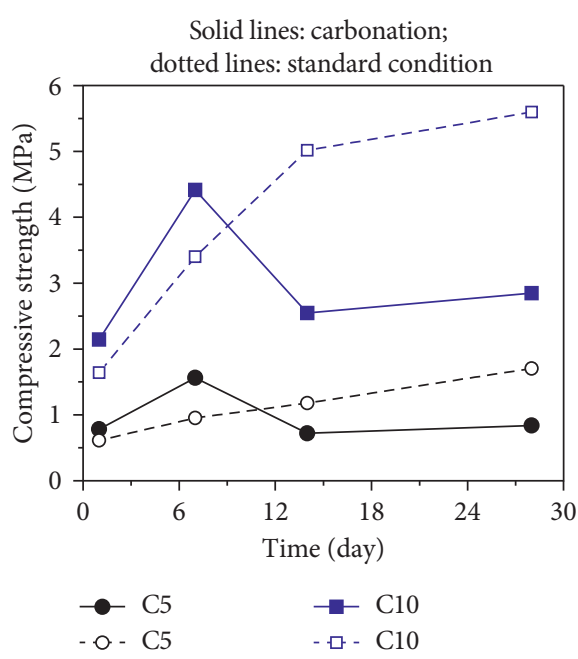

(b)

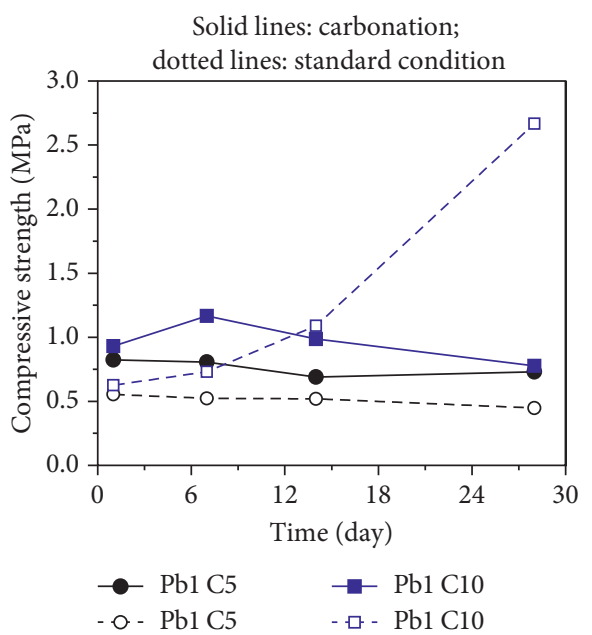

(d)

FIGURE 7: The unconfined compressive strength of solidified soil with different moisture contents. (a) Moisture content $=23 \%$. (b) Moisture content $=17 \%$. (c) Moisture content $=23 \%$. (d) Moisture content $=17 \%$.

the uncontaminated soil with $17 \%$ or $23 \%$ moisture content. Besides, "Pb1 17\% or Pb1 23\%" shown in Figure 8 indicates $1 \% \mathrm{~Pb}(\mathrm{II})$ contaminated soil with $17 \%$ or $23 \%$ moisture content. It shows that the specimens with $17 \%$ moisture content have higher compressive strengths than those with $23 \%$ moisture content in most cases in both standard and carbonation conditions. In this study, the agent has been able to react completely associated with relatively few cement.

Compared with samples cured under standard condition, the compressive strengths of carbonated specimens decline at the late stage (7-28 days). On one hand, cement hydration products are covered by carbonation precipitation generated by the precarbonation, which hinders the further occurrence of carbonation reaction and thereby decreases the strength of solidified soils. On the other hand, the decrease of pore volume of carbonated specimens also decreases the strength of solidified soil. This is because of the following reasons: (a) the increase of soil density, (b) the reduction of diffusion rate of carbon dioxide in the solidified soil, and (c) the decrease of carbonation reaction rate.

3.3. Carbonation Depth Analysis. The carbonation depth test results show that the depth of the cement-solidified soil is significantly enhanced with curing time. As shown in Figure 9, "M0" demonstrates the uncontaminated soil. The presence of heavy metal is beneficial to the carbonation depth of the solidified soil. At the moisture content of $23 \%$, the depths of $1 \% \mathrm{Cu}(\mathrm{II})$ or $\mathrm{Zn}(\mathrm{II})$ contaminated soils after 28 days (d) carbonation are $18 \mathrm{~mm}$, which are 1.8 times higher than those of clean soils.

Figure 10 presents the relationship between carbonation depth and heavy metal concentrations. At the early stage (7-14 days), the carbonation depth of the specimens with 


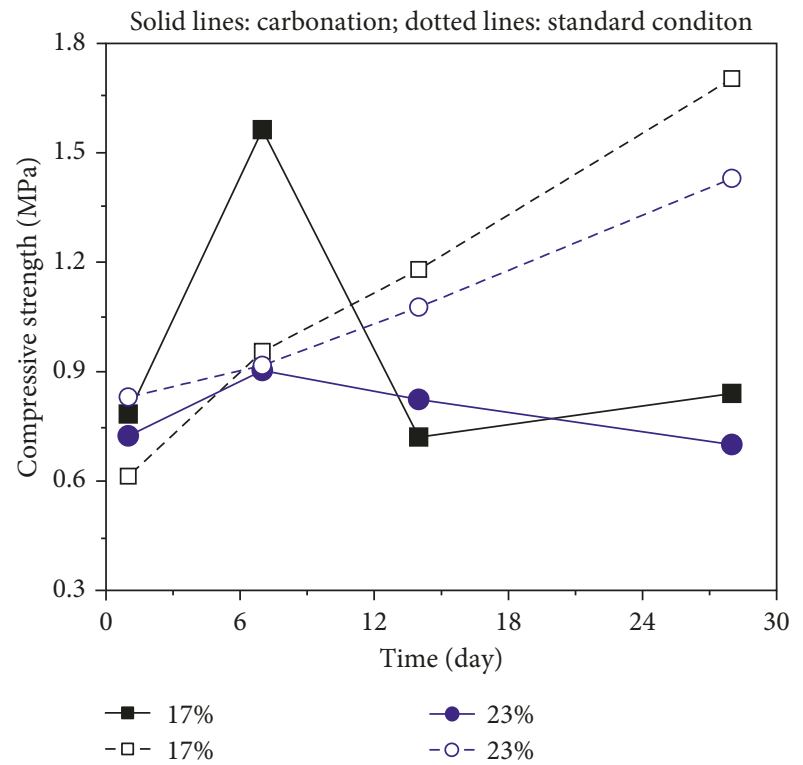

(a)

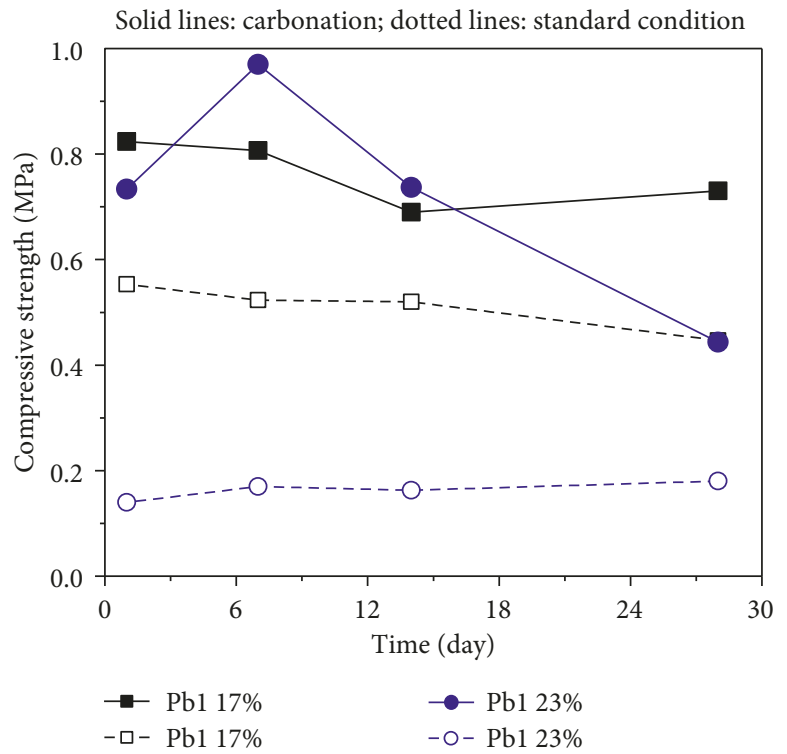

(c)

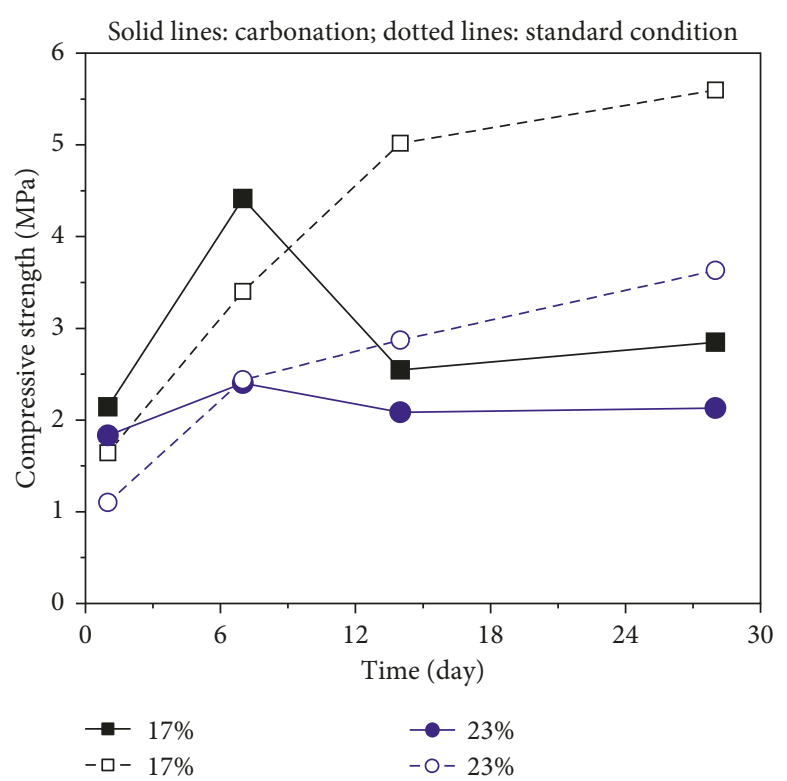

(b)

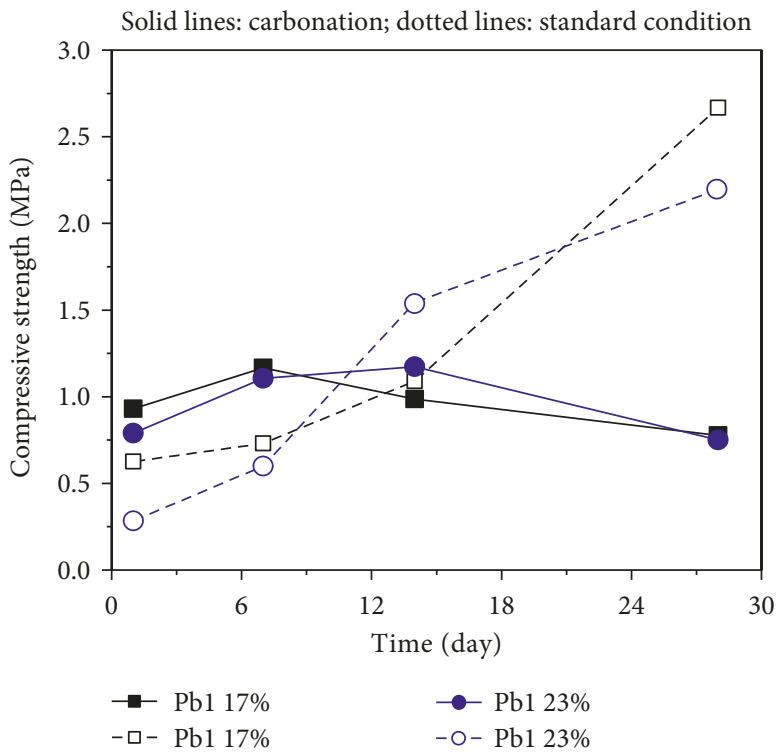

(d)

Figure 8: The unconfined compressive strength of solidified soil with different cement contents. (a) Cement content $=5 \%$. (b) Cement content $=10 \%$. (c) Cement content $=5 \%$. (d) Cement content $=10 \%$.

$23 \%$ moisture content and 5\% cement content grew rapidly with the increasing of heavy metal concentration. While in the late stage, immobilization of heavy metal consumed parts of $\mathrm{SiO}_{2}, \mathrm{Al}_{2} \mathrm{O}_{3}$, and $\mathrm{CaO}$ components in the cement or kaolin, which reduces the hydration and pozzolanic reaction materials. That is why the carbonation reactions with high contamination concentration and $17 \%$ moisture content are lower than those with low concentration or clean soil.

Figure 11 demonstrates the carbonation depths of solidified soil under different cement contents. The density of soil and carbonation reaction rate is highly related with cement content. Under the same level of heavy metal concentration and curing time, the samples with $10 \%$ cement content show smaller carbonation depths than those with $5 \%$ cement content. Regarding the moisture content, the connectivity of the liquid phase in the solidified soil decreases due to the relative low moisture content, which leading to the increase of porosities of samples. This explains that the carbonation depths of specimens with $17 \%$ moisture content are higher than those with $23 \%$ moisture content. 


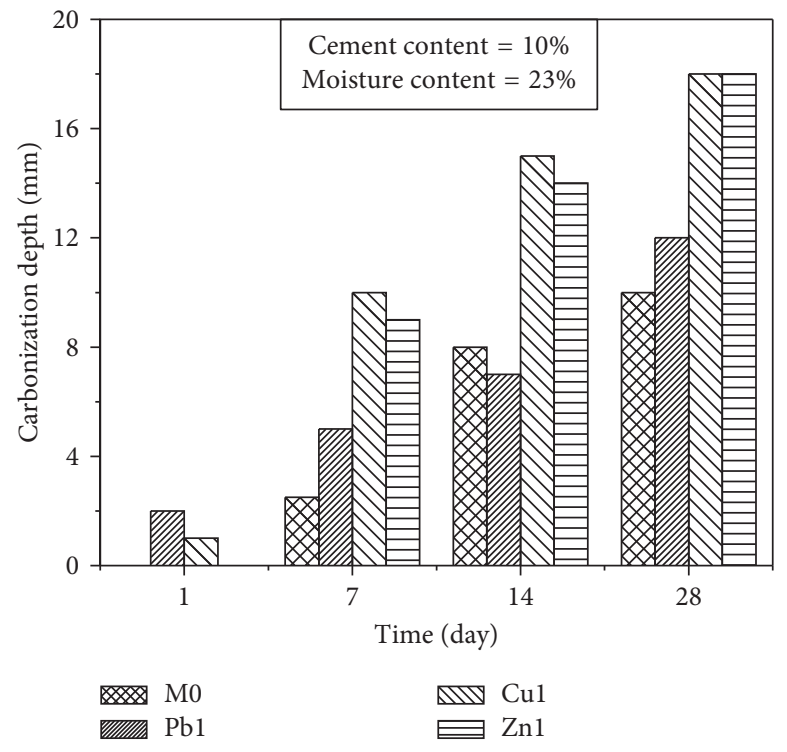

FIgURE 9: Carbonation depths of contaminated soil with different contaminations.

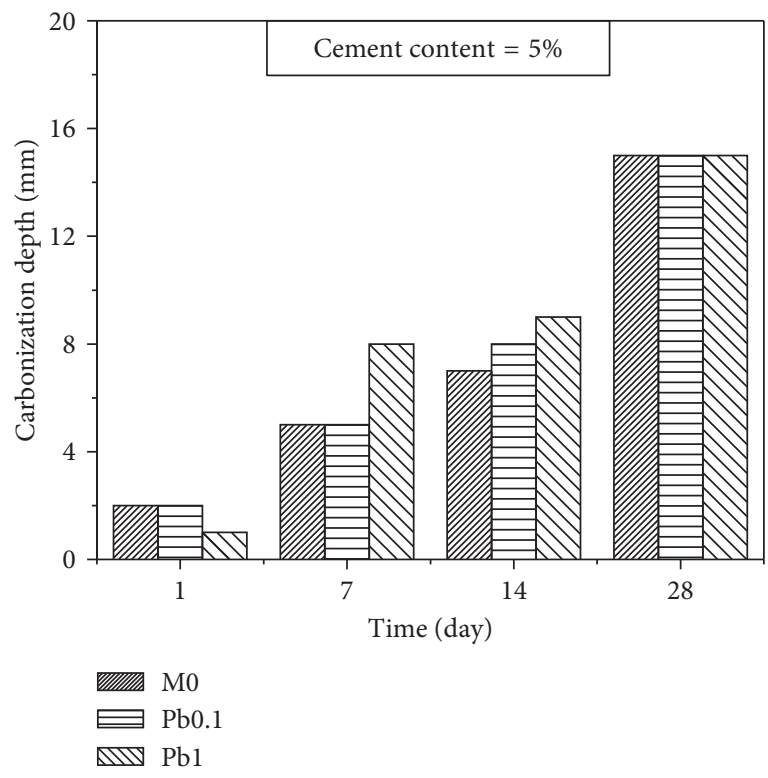

(a)

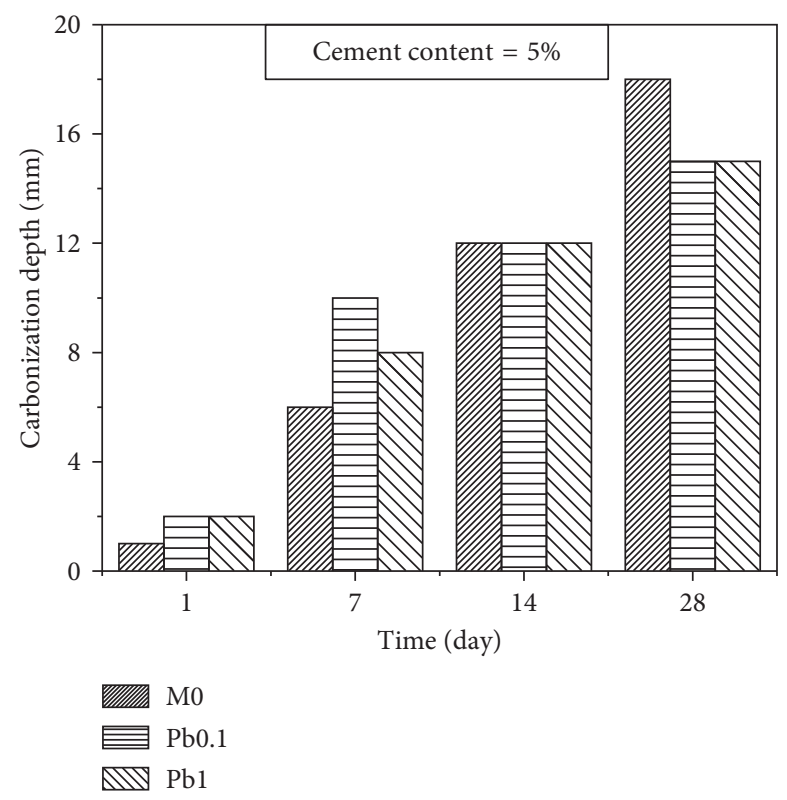

(b)

Figure 10: Carbonation depths of contaminated soil with different heavy metal contents. (a) Moisture content $=23 \%$. (b) Moisture content $=17 \%$.

\section{Simulation Results and Analysis}

This study uses the cement-solidified contaminated soil as road subgrade and explores the influences of subgrade modulus and vehicle load on pavement settlements.

4.1. Analysis of the Influence of Subgrade Modulus. The modulus of cement-treated material is a key mechanical factor to pavement design. Based on the experimental results, elasticity moduli of solidified soils under different conditions are shown in Table 6, in which the elasticity moduli of solidified $\mathrm{Pb}$ contaminated soil after $28 \mathrm{~d}$ curing under carbonation and standard condition range from 90.80 MPa to $210.28 \mathrm{MPa}$, from $36.87 \mathrm{MPa}$ to $546.19 \mathrm{MPa}$, respectively. In this study, the elasticity moduli of subgrade are set from $50 \mathrm{MPa}$ to $500 \mathrm{MPa}$.

Figure 12 shows the relationship between the elastic moduli of subgrade and the surface settlements of pavement. The surface settlement of the pavement decreases gradually with increasing of elastic modulus and the distance away from the load center. Comparing with 


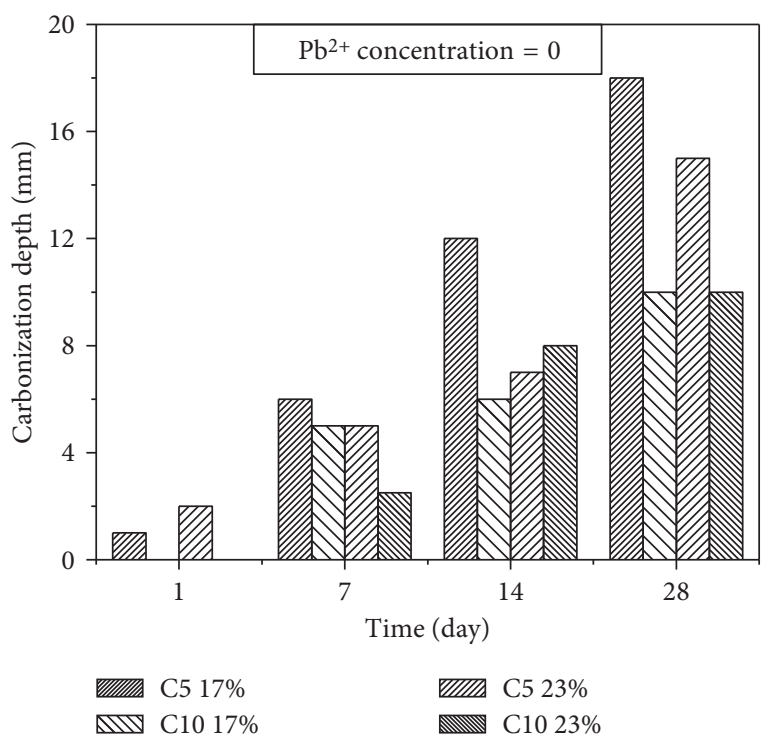

(a)

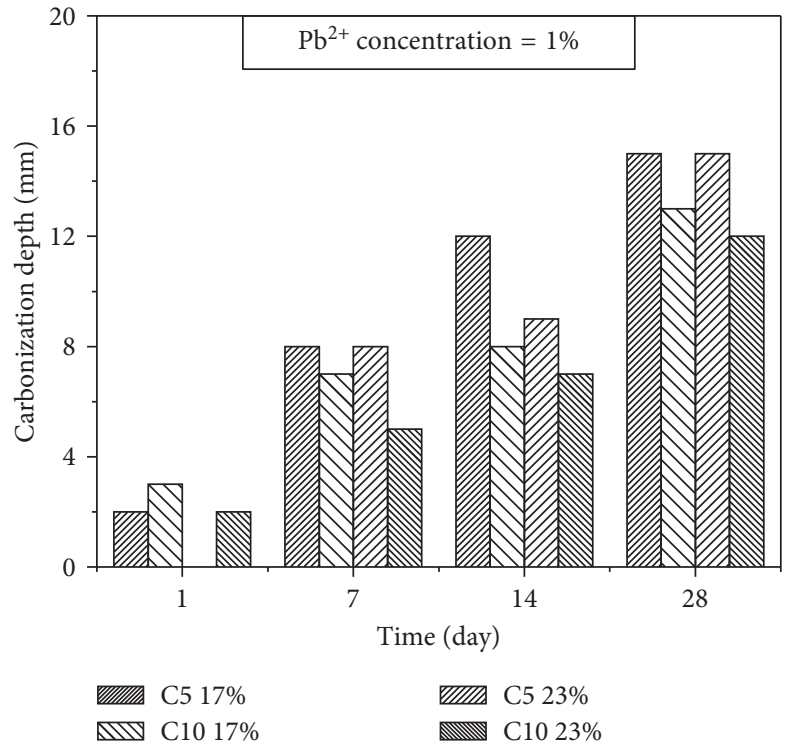

(b)

Figure 11: Carbonation depths of contaminated soil with different cement and moisture contents. (a) $\mathrm{Pb}^{2+}$ concentration $=0$. (b) $\mathrm{Pb}^{2+}$ concentration $=1 \%$.

TABLE 6: Elasticity moduli of solidified soils under different conditions.

\begin{tabular}{|c|c|c|c|c|c|c|c|c|c|c|}
\hline \multirow{3}{*}{ Heavy metal content (\%) } & \multirow{3}{*}{ Cement content (\%) } & \multirow{3}{*}{ Moisture content (\%) } & \multicolumn{8}{|c|}{$\mathrm{E}(\mathrm{MPa})$} \\
\hline & & & \multicolumn{4}{|c|}{ Carbonation $(\mathrm{d})$} & \multicolumn{4}{|c|}{ Standard condition $(\mathrm{d})$} \\
\hline & & & 1 & 7 & 14 & 28 & 1 & 7 & 14 & 28 \\
\hline \multirow{4}{*}{0} & 5 & 17 & 356.5 & 711.6 & 327.7 & 382.3 & 279.2 & 434.7 & 537.1 & 775.3 \\
\hline & 5 & 23 & 329.2 & 411.2 & 374.7 & 318.6 & 377.8 & 417.2 & 490.1 & 650.9 \\
\hline & 10 & 17 & 975.6 & 2008.8 & 1159.1 & 1295.7 & 748.0 & 1547.5 & 2283.4 & 2547.4 \\
\hline & 10 & 23 & 834.5 & 1093.9 & 948.2 & 969.5 & 500.7 & 1109.1 & 1306.3 & 1652.2 \\
\hline \multirow{2}{*}{ Pb0.1 } & 5 & 17 & 200.7 & 452.4 & 360.0 & 210.3 & 102.0 & 337.7 & 344.1 & 474.7 \\
\hline & 5 & 23 & 174.2 & 238.4 & 241.1 & 180.5 & 49.9 & 235.8 & 304.8 & 299.5 \\
\hline \multirow{4}{*}{$\mathrm{Pb} 1$} & 5 & 17 & 168.6 & 165.2 & 141.3 & 149.5 & 113.3 & 107.2 & 106.5 & 91.5 \\
\hline & 5 & 23 & 150.2 & 198.7 & 150.9 & 90.8 & 28.7 & 34.8 & 33.3 & 36.9 \\
\hline & 10 & 17 & 190.5 & 239.0 & 202.1 & 159.1 & 128.4 & 149.5 & 223.3 & 546.2 \\
\hline & 10 & 23 & 161.8 & 226.7 & 240.3 & 153.6 & 58.0 & 122.9 & 316.1 & 449.9 \\
\hline $\mathrm{Zn} 1$ & 10 & 23 & 134.5 & 105.1 & 105.5 & 101.0 & 23.9 & 29.4 & 20.5 & 23.2 \\
\hline $\mathrm{Cu} 1$ & 10 & 23 & 134.5 & 213.0 & 215.1 & 140.0 & 35.5 & 38.2 & 45.7 & 37.6 \\
\hline
\end{tabular}

the pavement settlements at the center, the settlements $2.5 \mathrm{~m}$ away from the center with elasticity moduli from $50 \mathrm{MPa}$ to $500 \mathrm{MPa}$ decline by $105.73 \%, 106.60 \%, 105.13 \%$, and $104.62 \%$, respectively, while the settlements at the edge decline by $109.92 \%$, 103.77\%, 102.56\%, and 103.08\%, respectively. Furthermore, along with the increase of elasticity moduli, surface settlements at the center decrease by $59.42 \%, 70.44 \%$, and $75.24 \%$, respectively. Thus, elasticity modulus plays a key role in the pavement settlement at the center.

4.2. Analysis of the Influence of Traffic Load. On the basis of BZZ-100 standard axle load, the vehicle loads are set to
0.7 $\mathrm{MPa}$ (standard axle load), 1.1 MPa (overload 50\%), and 1.4 MPa (overload 100\%). Such settings aim to investigate the influence of the traffic load.

The settlements of pavement with different traffic axle loads are presented in Figure 13. It is observed that traffic loads have a remarkable effect on the pavement settlements. With axle load increasing from $0.7 \mathrm{MPa}$ to $1.4 \mathrm{MPa}$, the surface settlements at the center increase rapidly by $57.14 \%$ and $100 \%$. It is indicated that the settlement at the centerline is linearly proportional to the axle load. In addition, the settlements of pavement have an inverse relationship with the distance away from the centerline. Compared with surface settlements at the center, the settlements 2.5 meter 


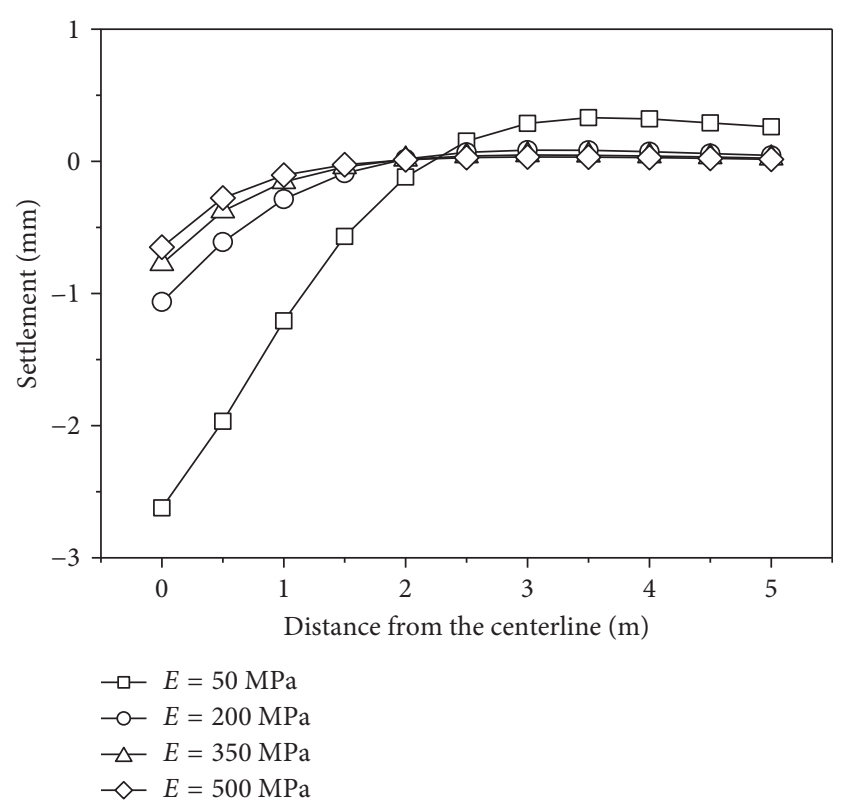

FIGURE 12: Settlements of the pavement with different subgrade moduli.

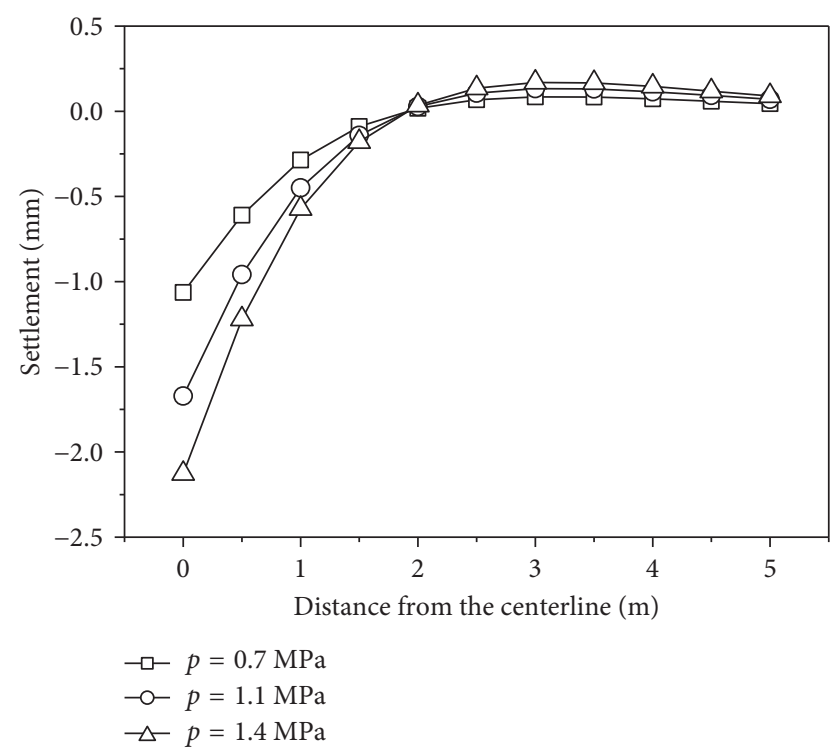

Figure 13: Settlements of the pavement with different axle loads.

away from the center with $0.7 \mathrm{MPa}, 1.1 \mathrm{MPa}$, and $1.4 \mathrm{MPa}$ decrease by $106.60 \%, 106.59 \%$, and $106.57 \%$, respectively. When the distance away from the center is more than 2.5 meter, traffic load is not the main factor affecting the pavement settlement.

\section{Conclusions}

This study evaluated the carbonation effects on strength and settlement of cement-solidified contaminated soil for the use of road subgrade. The major findings are summarized as follows:

(1) As far as initial contamination species, the compressive strengths of $\mathrm{Cu}(\mathrm{II})$ or $\mathrm{Zn}(\mathrm{II})$ contaminated soil $(\mathrm{Cu} 1 / \mathrm{Zn} 1)$ were lower than that of $\mathrm{Pb}$ (II) 1 and uncontaminated soil. Under both standard and carbonation conditions, compressive strengths of stabilized soils increased with curing time and declined sharply when the concentration of $\mathrm{Pb}$ (II) increased from 0 to $1 \%$. Regarding moisture content, specimens with $17 \%$ moisture content showed higher strengths compared to those with $23 \%$ moisture content under both standard and carbonation conditions.

(2) The carbonation depth was significantly enhanced with curing time and contamination concentration. Under the same condition, the samples with $10 \%$ cement content had smaller carbonation depth compared with those with 5\% cement content. In addition, the carbonation depths of specimens with $17 \%$ moisture content were higher than those with $23 \%$ moisture content.

(3) In the simulation, the surface settlements of the pavement decreased with the increase of elastic modulus and the distance away from the load center. Regarding traffic load, the settlement at the centerline was linearly proportional to the axle load. When the distance away from the center was more than 2.5 meter, traffic load was not a significant factor affecting the pavement settlement.

(4) Based on experimental and numerical analysis results, the strengths of the carbonated contaminated soil meet the standard of subgrade material, resulting in low settlement deformations. Therefore, the contaminated soils after carbonation possess long durability and carbonation resistance.

\section{Nomenclature}

S/S: Solidification/stabilization

XRD: X-ray diffraction

ICP: Inductive Coupled Plasma Emission Spectrometer

$\mathrm{N}_{2}$-BET: Nitrogen adsorption measurement

SEM: $\quad$ Scanning electron microscope

EC: $\quad$ Electrical conductivity

C5: $\quad 5 \%$ cement content

C10: $\quad 10 \%$ cement content

17\%: $\quad 17 \%$ moisture content

23\%: $\quad 23 \%$ moisture content

Pb0.1: $\quad 0.1 \% \mathrm{~Pb}(\mathrm{II})$ contaminated soil

$\mathrm{Pb} 1: \quad 1 \% \mathrm{~Pb}(\mathrm{II})$ contaminated soil

$\mathrm{Zn} 1: \quad 1 \% \mathrm{Zn}(\mathrm{II})$ contaminated soil

Cul: $\quad 1 \% \mathrm{Cu}(\mathrm{II})$ contaminated soil.

\section{Conflicts of Interest}

The authors declare that they have no conflicts of interest. 


\section{Acknowledgments}

The research presented herein is supported by the National Nature Science Foundation of China (51708377), Natural Science Foundation of Jiangsu Province (BK20170339), China Postdoctoral Science Foundation funded project (2016M591756), Natural Science Fund for Colleges and Universities in Jiangsu Province (17KJB560008), Jiangsu Planned Projects for Postdoctoral Research Funds (1601175C), and project from Jiangsu Provincial Department of Housing and Urban-Rural Development (2016ZD18 and 2017ZD002). The research is also supported by Jiangsu Provincial Transport Bureau (2016T05).

\section{References}

[1] Q. Tang, X. W. Tang, M. M. Hu, Z. Z. Li, Y. M. Chen, and P. Lou, "Removal of Cd(II) from aqueous solution with activated Firmiana Simplex Leaf: behaviors and affecting factors," Journal of Hazardous Materials, vol. 79, no. 1-3, pp. 95-103, 2010.

[2] Q. Tang, T. Katsumi, T. Inui, and Z. Z. Li, "Membrane behavior of bentonite amended compacted clay," Soils and Foundations, vol. 54, no. 3, pp. 329-344, 2014.

[3] Q. Tang, HJ. Kim, K. Endo, T. Katsumi, and T. Inui, "Size effect on lysimeter test evaluating the properties of construction and demolition waste leachate," Soils and Foundations, vol. 55, no. 4, pp. 720-736, 2015.

[4] Q. Tang, T. Katsumi, T. Inui, and Z. Z. Li, "Membrane behavior of bentonite-amended compacted clay towards $\mathrm{Zn}$ (II) and $\mathrm{Pb}(\mathrm{II}), "$ Membrane Water Treatment, vol. 6, no. 5, pp. 393-409, 2015.

[5] J. Escarré, C. Lefèbvre, S. Raboyeau et al., "Heavy metal concentration survey in soils and plants of the Les Malines Mining District (Southern France): implications for soil restoration," Water, Air, \& Soil Pollution, vol. 216, no. 1-4, pp. 485-504, 2011.

[6] A. A. Seleznev and I. V. Yarmoshenko, "Study of urban puddle sediments for understanding heavy metal pollution in an urban environment," Environmental Technology \& Innovation, vol. 1-2, pp. 1-7, 2014.

[7] M. CosKun, E. Steinnes, and M. Viladimirovna, "Heavy metal pollution of surface soil in the Thrace region, Turkey," Environmental Monitoring and Assessment, vol. 119, no. $1-3$, pp. $545-556,2006$.

[8] N. T. H. Ha, M. Sakakibara, S. Sano, and M. T. Nhuan, "Uptake of metals and metalloids by plants growing in a lead-zinc mine area, Northern Vietnam," Journal of Hazardous Materials, vol. 186, no. 2-3, pp. 1384-1391, 2011.

[9] W. H. Zhang, W. U. Ying-Xin, and M. O. Simonnot, "Soil contamination due to e-waste disposal and recycling activities: a review with special focus on China," Pedosphere, vol. 22, no. 4, pp. 434-455, 2012.

[10] Q. Tang, Y. Liu, F. Gu, and T. Zhou, "Solidification/ stabilization of fly ash from a municipal solid waste incineration facility using Portland cement," Advances in Materials Science and Engineering, vol. 2016, Article ID 7101243, 10 pages, 2016.

[11] Q. Tang, Y. Zhang, Y. F. Gao, and F. Gu, "Use of cementchelated solidified MSWI fly ash for pavement material: mechanical and environmental evaluations," Canadian Geotechnical Journal, vol. 54, no. 11, pp. 1553-1566, 2017.
[12] A. Bochenek and W. Kurdowski, "Influence of zinc phase on the properties of Portland cement," Cement Wapno Beton, vol. 18, pp. 52-58, 2013.

[13] C. Gu, Y. Liu, D. B. Liu et al., "Distribution and ecological assessment of heavy metals in irrigation channel sediments in a typical rural area of south China," Ecological Engineering, vol. 90, pp. 466-472, 2016.

[14] A. Kasassi, P. Rakimbei, and A. Karagiannidis, "Soil contamination by heavy metals: measurements from a closed unlined landfill," Bioresource Technology, vol. 99, no. 18, pp. 8578-8584, 2008.

[15] A. K. Krishna, K. Rama Mohan, N. N. Murthy et al., "Assessment of heavy metal contamination in soils around chromite mining areas, Nuggihalli, Karnataka," Environmental Earth Sciences, vol. 70, no. 2, pp. 699-708, 2013.

[16] Ministry of Environmental Protection; Ministry of Land and Resources, National Soil Pollution Survey Bulletin, PRC, London, UK, 2014, http://www.zhb.gov.cn/gkml/hbb/qt/ 201404/t20140417_270670.htm.

[17] C. Vandecasteele, V. Dutré, D. Geysen, and G. Wauters, "Solidification/stabilisation of arsenic bearing fly ash from the metallurgical industry. Immobilisation mechanism of arsenic," Waste Management, vol. 22, no. 2, pp. 143-146, 2002.

[18] D. Dermatas, D. H. Moon, N. Menounou, X. Meng, and R. Hires, "An evaluation of arsenic release from monolithic solids using a modified semi-dynamic leaching test," Journal of Hazardous Materials, vol. 116, no. 1-2, pp. 25-38, 2004.

[19] F. Rosquoet, L. Thorel, J. Garnier, and Y. Canepa, "Lateral cyclic loading of sand-installed piles," Soils and Foundations, vol. 47, no. 5, pp. 821-832, 2007.

[20] W. Ashraf, "Carbonation of cement-based materials: challenges and opportunities," Construction and Building Materials, vol. 120, pp. 558-570, 2016.

[21] A. Fabbri, J. Corvisier, A. Schubnel, F. Brunet, B. Goffé, and G. Rimmele, "Effect of carbonation on the hydro-mechanical properties of Portland cements," Cement and Concrete Research, vol. 39, no. 12, pp. 1156-1163, 2009.

[22] P. J. Gunning, C. D. Hills, and P. J. Carey, "Accelerated carbonation treatment of industrial wastes," Waste Management, vol. 30, no. 6, pp. 1081-1090, 2010.

[23] L. D. Poulikakos, C. Papadaskalopoulou, B. Hofko et al., "Harvesting the unexplored potential of European waste materials for road construction," Resources, Conservation and Recycling, vol. 116, pp. 32-44, 2017.

[24] J. Jime'nez, J. Ayuso, and F. Agrela, "Use of mixed recycled aggregates with a low embodied energy from non-selected CDW in unpaved rural roads," Construction and Building Materials, vol. 34, pp. 34-43, 2012.

[25] R. M. Brooks and M. Cetin, "Application of construction demolition waste for improving performance of subgrade and subbase layers," International Journal of Research and Reviews in Applied Sciences, vol. 12, no. 3, p. 375, 2012.

[26] T. Bennert, W. Papp, A. Maher, and N. Gucunski, "Utilization of construction and demolition debris under traffic-type loading in base and subbase applications," Transportation Research Record: Journal of the Transportation Research Board, vol. 1714, pp. 33-39, 2000.

[27] A. C. Garrabrants, F. Sanchez, and D. S. Kosson, "Changes in constituent equilibrium leaching and pore water characteristics of a portland cement mortar as a result of carbonation," Waste Management, vol. 24, no. 1, pp. 19-36, 2004.

[28] M. V. B. Krishna, K. Chandrasekaran, S. Chakravarthy, and D. Karunasagar, "An integrated approach based on oxidative pyrolysis and microwave-assisted digestion for the multi- 
elemental analysis of coal samples by ICP-based techniques," Fuel, vol. 158, pp. 770-778, 2015.

[29] Q. Tang, X. W. Tang, Z. Z. Li, Y. M. Chen, N. Y. Kou, and Z. F. Sun, "Adsorption and desorption behaviour of $\mathrm{Pb}$ (II) on a natural kaolin: equilibrium, kinetic and thermodynamic studies," Journal of Chemical Technology \& Biotechnology, vol. 84, no. 9, pp. 1371-1380, 2009.

[30] Q. Tang, X. W. Tang, Z. Z. Li et al., “Zn(II) removal with activated firmiana simplex leaf: kinetics and equilibrium studies," Journal of Environmental Engineering, vol. 138, no. 2, pp. 190-199, 2012.

[31] Q. Tang, T. Katsumi, T. Inui, and Z. Z. Li, "Influence of $\mathrm{pH}$ on the membrane behavior of bentonite amended Fukakusa clay," Separation and Purification Technology, vol. 141, pp. 132-142, 2015.

[32] Q. Tang, W. Liu, H. Y. Wang, R. Cheng, and Y. F. Qian, "Membrane behavior of bentonite-amended Fukakusa clay under K, Na and Ca solutions," Journal of Central South University, vol. 23, no. 12, pp. 3122-3131, 2016.

[33] L. Pu and C. Unluer, "Investigation of carbonation depth and its influence on the performance and microstructure of $\mathrm{MgO}$ cement and PC mixes," Construction \& Building Materials, vol. 120, pp. 349-363, 2016.

[34] Q. Tang, LL. Pan, Y. F. Gao et al., "Study on strength and environmental behaviors of solidified fly ash under carbonation effect," Chinese Journal of Geotechnical Engineering, 2017, TU.20171029.1321.004.html.

[35] Rilem, "Measurement of hardened concrete carbonation depth," Materials and Structures, vol. 21, no. 6, pp. 453-455, 1998.

[36] X. Zha, H. Wang, P. Xie, C. Wang, P. Dangla, and J. Ye, "Leaching resistance of hazardous waste cement solidification after accelerated carbonation," Cement and Concrete Composites, vol. 72, pp. 125-132, 2016.

[37] L. Hu, J. Hao, and L. Wang, "Laboratory evaluation of cement treated aggregate containing crushed clay brick," Journal of Traffic and Transportation Engineering, vol. 1, no. 5, pp. 371-382, 2014.

[38] F. Gu, H. Sahin, X. Luo, R. Luo, and R. L. Lytton, "Estimation of resilient modulus of unbound aggregates using performance-related base course properties," Journal of Materials in Civil Engineering, vol. 27, no. 6, p. 04014188, 2014.

[39] F. Gu, Y. Zhang, C. V. Droddy, R. Luo, and R. L. Lytton, "Development of a new mechanistic empirical rutting model for unbound granular material," Journal of Materials in Civil Engineering, vol. 28, no. 8, p. 04016051, 2015.

[40] F. Gu, Y. Zhang, X. Luo, H. Sahin, and R. L. Lytton, "Characterization and prediction of permanent deformation properties of unbound granular materials for pavement $\mathrm{ME}$ design," Construction and Building Materials, vol. 155, pp. 584-592, 2017.

[41] F. Gu, X. Luo, R. C. West, A. J. Taylor, and N. D. Moore, "Energy-based crack initiation model for load-related topdown cracking in asphalt pavement," Construction and Building Materials, vol. 159, pp. 587-597, 2018.

[42] F. Gu, X. Luo, Y. Zhang, and R. L. Lytton, "Using overlay test to evaluate fracture properties of field-aged asphalt concrete," Construction and Building Materials, vol. 101, pp. 1059-1068, 2015.

[43] X. Luo, F. Gu, and R. L. Lytton, "Mechanistic compositionspecific fatigue life of asphalt pavements," Journal of Engineering Mechanics, vol. 143, no. 12, p. 04017136, 2017.
[44] F. Gu, X. Luo, Y. Zhang, R. L. Lytton, and H. Sahin, "Modeling of unsaturated granular materials in flexible pavements," E3S Web of Conferences, vol. 9, p. 20002, 2016.

[45] F. Gu, X. Luo, R. Luo, R. L. Lytton, E. Y. Hajj, and R. V. Siddharthan, "Numerical modeling of geogridreinforced flexible pavement and corresponding validation using large-scale tank test," Construction and Building Materials, vol. 122, pp. 214-230, 2016.

[46] K. Himeno, T. Kamijima, T. Ikeda, and T. Abe, "Distribution of tire contact pressure of vehicles and its influence on pavement distress," in Proceedings of Eighth International Conference on Asphalt Pavements, Seattle, WA, USA, 1997.

[47] M. Terashi, H. Tanaka, T. Mitsumoto, Y. Niidome, and S. Homma, "Fundamentalproperties of lime and cement treated soils," Report of the Port and Harbour Research Institute, vol. 22, pp. 69-96, 1980.

[48] Y. J. Du, M. L. Wei, F. Jin, and Z. B. Liu, "Stress-strain relation and strength characteristics of cement treated zinccontaminated clay," Engineering Geology, vol. 167, pp. 2026, 2013.

[49] M. Yang and X. H. Zhao, "An approach for a single pile in layered soil," Journal of Tongji University, vol. 20, pp. 421-427, 1992.

[50] X. N. Gong, Foundation Treatment Manual, China Architecture and Building Press, Beijing, China, 3rd edition, 2008.

[51] Y. J. Du, M. L. Wei, K. R. Reddy, F. Jin, H. L. Wu, and Z. B. Liu, "New phosphate-based binder for stabilization of soils contaminated with heavy metals: leaching, strength and microstructure characterization," Journal of Environmental Management, vol. 146, pp. 179-188, 2014.

[52] S. Mignardi, A. Corami, and V. Ferrini, "Evaluation of the effectiveness of phosphate treatment for the remediation of mine waste soils contaminated with $\mathrm{Cd}, \mathrm{Cu}, \mathrm{Pb}$, and $\mathrm{Zn}$," Chemosphere, vol. 86, no. 4, pp. 354-360, 2012.

[53] A. Navarro, E. Cardellach, and M. Corbella, "Immobilization of $\mathrm{Cu}, \mathrm{Pb}$ and $\mathrm{Zn}$ in mine-contaminated soils using reactive materials," Journal of Hazardous Materials, vol. 186, no. 2-3, pp. 1576-1585, 2011.

[54] P. Desogus, P. P. Manca, G. Orru, and A. Zucca, "Stabilization-solidification treatment of mine tailings using Portland cement, potassium dihydrogen phosphate and ferric chloride hexahydrate," Minerals Engineering, vol. 45, pp. 47-54, 2013.

[55] Y. J. Du, M. L. Wei, K. R. Reddy, and H. L. Wu, "Effect of carbonation on leachability, strength and microstructural characteristics of KMP binder stabilized $\mathrm{Zn}$ and $\mathrm{Pb}$ contaminated soils," Chemosphere, vol. 144, pp. 1033-1042, 2016.

[56] S. Bin Shafique, J. Walton, N. Gutierrez, R. Smith, and A. Tarquin, "Influence of carbonation on leaching of cementitious waste forms," Journal of Environmental Engineering, vol. 124, no. 5, pp. 463-467, 1998.

[57] C. Gervais, A. Garrabrants, F. Sanchez, and R. Barna, "The effects of carbonation and drying during intermittent leaching on the release of inorganic constituents from a cement-based matrix," Cement and Concrete Research, vol. 34, no. 1, pp. 119-131, 2004.

[58] M. F. Bertos, S. J. R. Simons, C. D. Hills, and P. J. Carey, “A review of accelerated carbonation technology in the treatment of cement-based materials and sequestration of $\mathrm{CO}_{2}$," Journal of Hazardous Materials, vol. 112, no. 3, pp. 193-205, 2004.

[59] Q. Tang, J. M. Chu, Y. Wang, T. Zhou, and Y. Liu, "Characteristics and factors influencing $\mathrm{Pb}$ (II) desorption from a Chinese clay by citric acid," Separation Science and Technology, vol. 51, no. 17, pp. 2734-2743, 2016. 
[60] Q. Tang, T. Zhou, F. Gu, Y. Wang, and J. M. Chu, "Removal of $\mathrm{Cd}(\mathrm{II})$ and $\mathrm{Pb}(\mathrm{II})$ from soil through desorption using citric acid: kinetic and equilibrium studies," Journal of Central South University, vol. 24, no. 9, pp. 1941-1952, 2017.

[61] Q. Tang, H. Y. Wang, X. W. Tang, and Y. Wang, "Removal of aqueous $\mathrm{Ni}(\mathrm{II})$ with carbonized leaf powder: kinetic and equilibrium studies," Journal of Central South University, vol. 23, no. 4, pp. 778-786, 2016. 


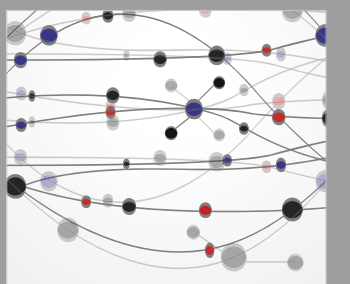

The Scientific World Journal
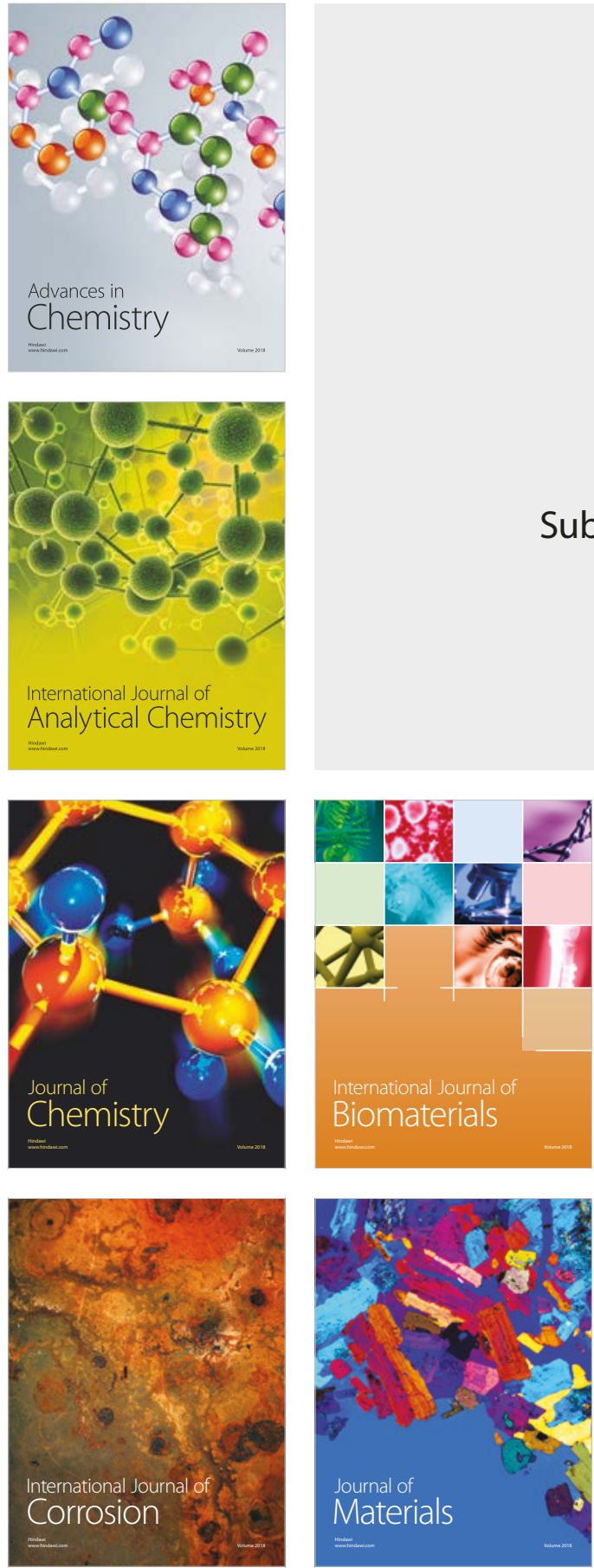

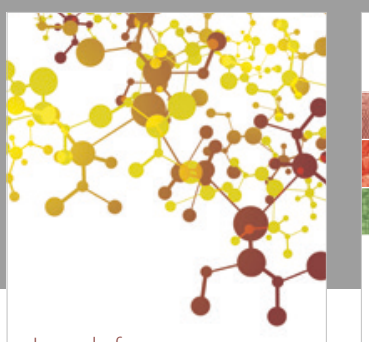

Journal of

Applied Chemistry
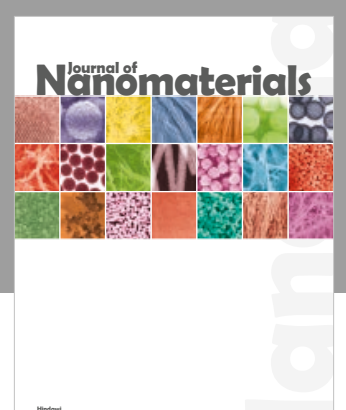

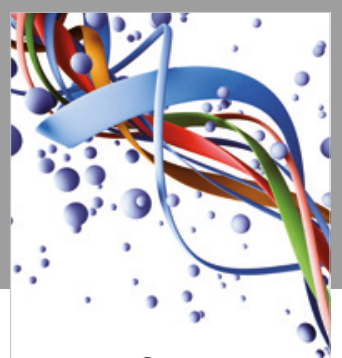

Scientifica

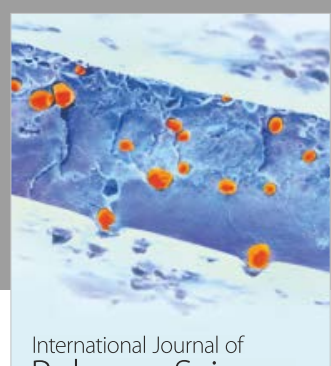

Polymer Science

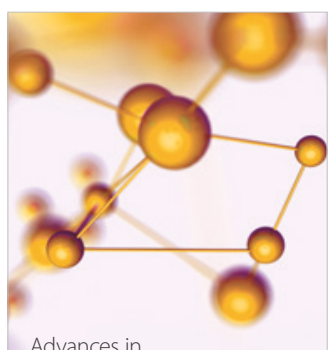

Physical Chemistry
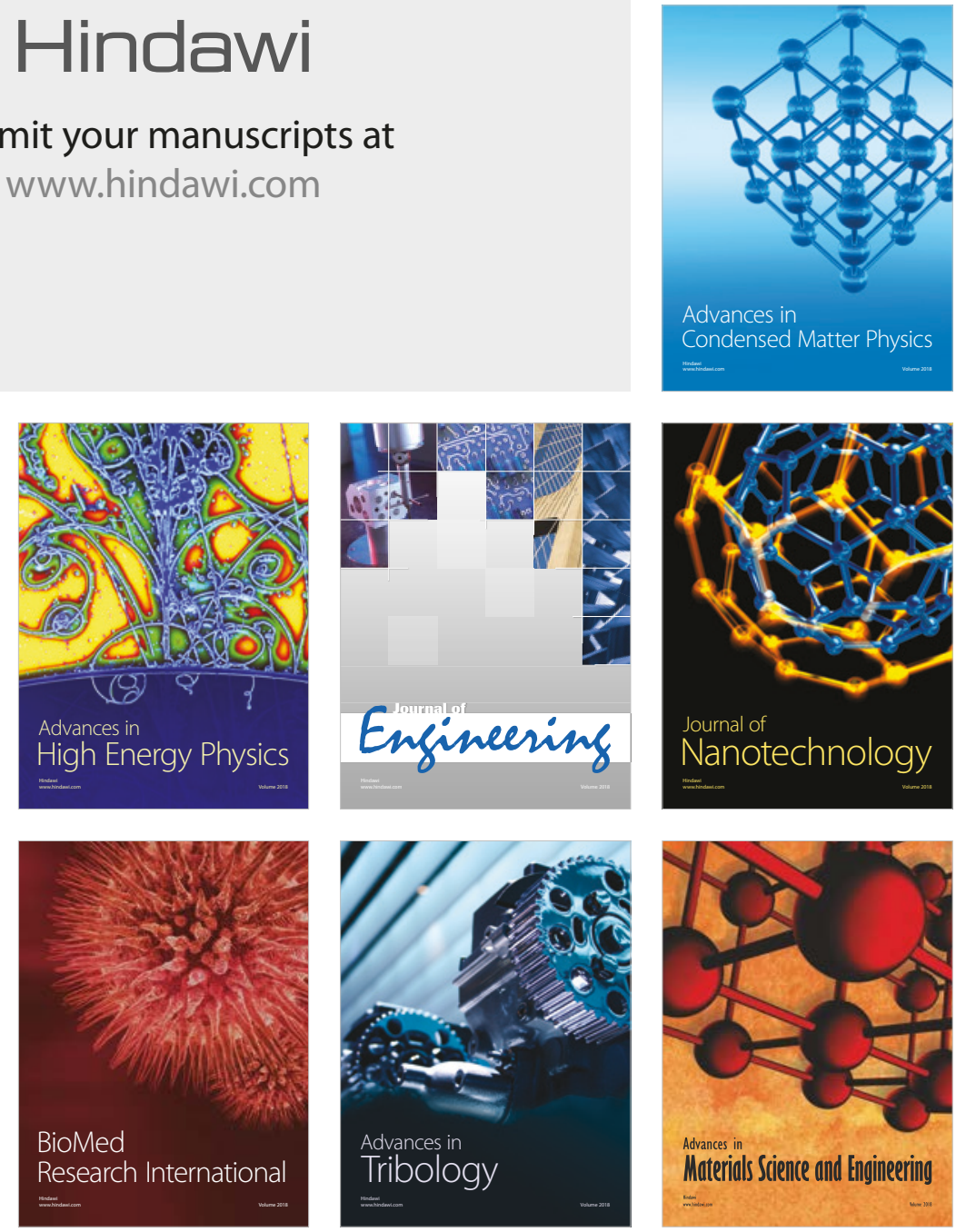